Article

\title{
Evaluation of Tumor-Targeting Properties of an Antagonistic Bombesin Analogue RM26 Conjugated with a Non-Residualizing Radioiodine Label Comparison with a Radiometal-Labelled Counterpart
}

\author{
Maryam Oroujeni 1,+(D), Ayman Abouzayed ${ }^{2,+}$, Fanny Lundmark ${ }^{2}$, Bogdan Mitran ${ }^{2}$, \\ Anna Orlova ${ }^{2,3}$, Vladimir Tolmachev ${ }^{1, *(\mathbb{D})}$ and Ulrika Rosenström ${ }^{2}$ \\ 1 Department of Immunology, Genetics and Pathology, Uppsala University, SE-751 85 Uppsala, Sweden \\ 2 Department of Medicinal Chemistry, Uppsala University, SE-751 23 Uppsala, Sweden \\ 3 Science for Life Laboratory, Uppsala University, SE-750 03 Uppsala, Sweden \\ * Correspondence: Vladimir.tolmachev@igp.uu.se; Tel.: +46-070-425-0782 \\ + These authors contributed equally to this work.
}

Received: 13 June 2019; Accepted: 24 July 2019; Published: 2 August 2019

\begin{abstract}
Radiolabelled antagonistic bombesin analogues are successfully used for targeting of gastrin-releasing peptide receptors (GRPR) that are overexpressed in prostate cancer. Internalization of antagonistic bombesin analogues is slow. We hypothesized that the use of a non-residualizing radioiodine label might not affect the tumour uptake but would reduce the retention in normal organs, where radiopharmaceutical would be internalized. To test this hypothesis, tyrosine was conjugated via diethylene glycol linker to N-terminus of an antagonistic bombesin analogue RM26 to form Tyr-PEG - RM26. [ ${ }^{111}$ In]In-DOTA-PEG - -RM26 was used as a control with a residualizing label. Tyr-PEG $2-\mathrm{RM} 26$ was labelled with ${ }^{125} \mathrm{I}$ with $95 \%$ radiochemical purity and retained binding specificity to GRPR. The $\mathrm{IC}_{50}$ values for Tyr-PEG $-\mathrm{RM} 26$ and DOTA-PEG $2-\mathrm{RM} 26$ were $1.7 \pm 0.3 \mathrm{nM}$ and $3.3 \pm 0.5 \mathrm{nM}$, respectively. The cellular processing of [ $\left.{ }^{125} \mathrm{I}\right] \mathrm{I}-\mathrm{Tyr}-\mathrm{PEG}_{2}-\mathrm{RM} 26$ by PC-3 cells showed unusually fast internalization. Biodistribution showed that uptake in pancreas and tumour was GRPR-specific for both radioconjugates. Blood clearance of $\left[{ }^{125} \mathrm{I}\right] \mathrm{I}-\mathrm{Ty}-\mathrm{PEG}_{2}-\mathrm{RM} 26$ was appreciably slower and activity accumulation in all organs was significantly higher than for $\left.{ }^{1111} \mathrm{In}\right] \mathrm{In}-\mathrm{DOTA}-\mathrm{PEG}_{2}-\mathrm{RM} 26$. Tumor uptake of $\left[{ }^{111}\right.$ In]In-DOTA-PEG $2-R M 26$ was significantly higher than for $\left.{ }^{125} \mathrm{I}\right] \mathrm{I}-\mathrm{Ty}-\mathrm{PEG}_{2}-\mathrm{RM} 26$, resulting in higher tumour-to-organ ratio for $\left.{ }^{111} \mathrm{In}\right] \mathrm{In}-\mathrm{DOTA}-\mathrm{PEG}_{2}-\mathrm{RM} 26$ at studied time points. Incorporation of amino acids with hydrophilic side-chains next to tyrosine might overcome the problems associated with the use of tyrosine as a prosthetic group for radioiodination.
\end{abstract}

Keywords: prostate cancer; bombesin antagonistic analogue; GRPR; RM26; tyrosine; PC-3 xenografts

\section{Introduction}

Prostate cancer (PC) is the second leading cause of cancer-related fatality in men [1]. The treatment of disseminated castration-resistant PC requires a systemic targeting approach. As the androgen receptor (AR) is the main oncogenic driver in PC, most drugs for its treatment are used to inhibit AR activity. However, since resistance to both first- and second-line androgen deprivation therapies (ADT) is a common problem, development of drugs towards other targets for visualization and treatment of PC is of utmost importance [2,3].

Targeting of prostate-specific membrane antigen (PSMA) is currently the major focus in development of a targeted radionuclide therapy of PC and its metastases $[4,5]$. There is no known 
natural ligand for PSMA, and the reason for PSMA upregulation in PC remains unknown [6-8]. The PSMA is highly expressed on prostate epithelial cells and strongly upregulated in PC. However, PSMA is not specific to the prostate gland and is expressed in other normal tissues (salivary glands, duodenal mucosa, and subpopulation of neuroendocrine cells in the colonic crypts) and neoplastic tissues. Xerophthalmia and xerostomia are often observed side-effects of PSMA-targeted radionuclide therapy inhibitors because of accumulation in salivary and lacrimal glands [4,5]. Therefore, it is desirable to develop agents targeting other PC-specific molecular alterations.

A possible therapeutic target in PC is gastrin-releasing peptide receptor (GRPR/BB2), a membrane bound G-protein coupled receptor. This receptor is a member of the bombesin receptor family together with neuromedin B receptor (NMBR/BB1), bombesin receptor subtype 3 (BB3) and subtype 4 (BB4). Overexpression of GRPR has been reported in PC amongst other cancer forms [9]. This, together with the low GRPR expression in healthy tissue, makes it a promising target in PC.

The use of peptide ligands and their analogues for tumour targeting has shown advantages such as excellent vascular permeability and rapid penetration into tumour [10]. Gastrin-releasing peptide (GRP) derivatives have shown high affinity to GRPR and are used in clinical studies [11]. Bombesin (BN) is a linear tetradecapeptide, an analogue of the mammalian GRP, which binds to GRPR with high affinity [12]. Since bombesin was assumed to be more stable than GRP, a number of bombesin-based targeting agents have been extensively investigated in preclinical and clinical studies for imaging and therapy [13-17].

Peptide-based agonists have been considered earlier as more preferable targeting agents compared to antagonists, because the rapid internalization of agonists along with residualizing radiometal labels could provide a high tumour accumulation, resulting in high tumour-to-background ratios [18-20]. The major disadvantage is systemic physiologic action. To overcome the disadvantages associated with agonist-based bombesin analogues, antagonists were introduced [21,22]. Antagonistic bombesin-based peptides have shown several other advantages compared to agonists such as more favourable biodistribution and targeting properties, and more binding sites available for targeting than agonists, which may make them preferable over agonists for in vivo tumour targeting [23-27].

Radiometal-labelled antagonistic bombesin analogues have demonstrated efficient targeting of GRPR-expressing tumours. However, internalization of bombesin antagonists by cancer cells was slow. Thus, the use of residualizing properties of a label should not be critical for efficient tumour targeting. We have shown earlier for slowly internalizing scaffold-protein-based agents that the use of non-residualizing labels offers advantage of rapid release of radionuclide from normal tissues after off-target interactions followed by internalization of targeting agents $[28,29]$. We hypothesized that the residualizing properties of the label for GRPR antagonist are not critical for a good tumour retention but a non-residualizing label would provide quicker clearance from normal tissues.

A possible therapeutic nuclide providing a non-residualizing label is iodine-131, a medium-energy beta-emitter. In preclinical studies, iodine-131 is often substituted by the convenient surrogate, iodine-125, a low energy gamma emitter with a half-life of 59.4 days. Radioiodine can be covalently bound to targeting proteins and peptides containing an activated phenolic ring, for example, a tyrosine residue using an electrophilic reaction [30]. Since the bombesin does not contain any tyrosine, or other moiety with activated phenolic ring, an incorporation of tyrosine is desirable for iodination.

Several studies have shown that the antagonistic bombesin analogue RM26 (D-Phe-GlnTrp-Ala-Val-Gly-His-Sta-Leu- $\mathrm{NH}_{2}$ ) [31], labelled with different radionuclides such as ${ }^{68} \mathrm{Ga}$ [32-34], ${ }^{111} \mathrm{In}[24,32],{ }^{18} \mathrm{~F}$ [35], ${ }^{55 / 57} \mathrm{Co}[36]$, and ${ }^{177} \mathrm{Lu}$ [37] containing different chelators, is a potential targeting agent for in vivo targeting of GRPR-expressing tumours. Previous structure-activity studies have demonstrated that modification at C-terminal region of bombesin resulted in dramatic reduction of the receptor binding affinity [38]. Therefore, the N-terminal of these analogues was used for coupling

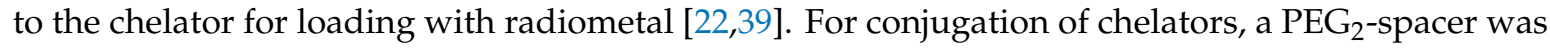
introduced at N-terminus of RM26. This linker prevents interference of a nuclide-chelator complex in 
binding of RM26 to the receptors [40]. For development of radioiodine labelled analogue, we have conjugated a tyrosine instead of chelator to the $\mathrm{PEG}_{2}$ linker.

The goal of this study was to evaluate the tumour-targeting properties of an antagonistic bombesin analogue labelled with non-residualizing $\left({ }^{125} \mathrm{I}-\mathrm{Tyr}\right)$ and labels residualizing $\left({ }^{111} \mathrm{In}\right.$-DOTA). For this purpose, the nine-amino-acid bombesin analogue RM26 was synthesized and N-terminus conjugated to tyrosine (Tyr) or DOTA via the diethylene glycol chain $\left(\mathrm{PEG}_{2}\right)$ to form Tyr- $\mathrm{PEG}_{2}-\mathrm{RM} 26$ and DOTA-PEG $2-R M 26$, respectively (Figure 1). Tyr-PEG $-\mathrm{PM}_{2} 6$ was labelled with radiohalogen iodine-125 and in vitro and in vivo properties of $\left[{ }^{125} \mathrm{I}\right] \mathrm{I}-\mathrm{Tyr}-\mathrm{PEG}_{2}-\mathrm{RM} 26$ were studied and compared to properties of $\left[{ }^{111} \mathrm{In}\right] \mathrm{In}-\mathrm{DOTA}-\mathrm{PEG}_{2}-\mathrm{RM} 26$ having a residualizing label.

\section{Materials and Methods}

\subsection{Peptide Synthesis and Characterization}

The bombesin analogue Tyr-PEG $2-\left[\mathrm{D}-\mathrm{Phe}^{6}, \mathrm{Sta}^{13}\right.$, Leu $\left.{ }^{14}\right]$ bombesin [6-14] (denoted as Tyr-PEG 2 -RM26) was synthesized by manual solid-phase peptide synthesis (SPPS) using standard Fmoc/t-Bu conditions, similar to previously described method [32]. The identity and purity was confirmed by analytical HPLC/ESI-MS using a Dionex UltiMate 3000 HPLC (Thermo Fisher Scientific, Waltham, MA, USA) system with a Bruker amazon SL ion trap mass spectrometer and detection by UV (diode array detector, 214, 254 and $280 \mathrm{~nm}$ ). The crude Tyr-PEG $2-R M 26$ was purified using reversed-phase high-performance liquid chromatography (RP-HPLC) (UV-triggered $(220 \mathrm{~nm})$ fraction collection with a Dionex UltiMate 3000 HPLC system, using an Macherey-Nagel Nucleodur C18 column $(21 \times 125 \mathrm{~mm}, 5 \mu \mathrm{m}$ particle size $)$.

DOTA-PEG $2-\left[\mathrm{D}-\mathrm{Phe}^{6}, \mathrm{Sta}^{13}{ }^{13} \mathrm{Leu}^{14}\right]$ bombesin [6-14] (denoted as DOTA-PEG $2-\mathrm{RM} 26$ ) was synthesized and characterized as previously described [34].

\subsection{Radiolabelling and In Vitro Stability Test}

For labelling with ${ }^{125} \mathrm{I}, \mathrm{Tyr}-\mathrm{PEG}_{2}-\mathrm{RM} 26$ was reconstituted in Milli-Q water to obtain a concentration of $0.7 \mathrm{mg} / \mathrm{mL}$ (stock solution). Then, Tyr-PEG $2-\mathrm{RM}_{2} 6$ solution $(2 \mu \mathrm{L}, 1 \mathrm{nmol})$ was mixed with $40 \mu \mathrm{L}$ PBS in a Pierce Iodination Tube (Thermo Fisher Scientific, Waltham, MA, USA), which activates iodine-125. $4 \mu \mathrm{L}$ of ${ }^{125}$ I-sodium iodide (8-15 MBq) was added. The reaction mixture was incubated at room temperature for $15 \mathrm{~min}$. Radiochemical yield was determined using high-performance liquid chromatography (HPLC), conducted on an Elite LaChrom system (Hitachi, VWR, Darmstadt, Germany) consisting of an L-2130 pump, a UV detector (L-2400), and a radiation flow detector (Bioscan, Washington, DC, USA) coupled in series. The radiolabelled conjugate was isolated by preparative-HPLC. HPLC conditions were as follows: $\mathrm{A}=10 \mathrm{mM}$ TFA $/ \mathrm{H}_{2} \mathrm{O} ; \mathrm{B}=10 \mathrm{mM}$ TFA/acetonitrile (MeCN); UV-detection at $220 \mathrm{~nm}$; gradient elution: $0-15 \mathrm{~min}$ at 5 to $70 \% \mathrm{~B}, 15-18 \mathrm{~min}$ at 70 to $95 \% \mathrm{~B}$, $19-20 \mathrm{~min}$ at $5 \% \mathrm{~B}$; and flow rate was $1.0 \mathrm{~mL} / \mathrm{min}$. The labelled compound was separated using an analytical column (Phenemenex, Aschaffenburg, Germany; Luna ${ }^{\circledR} 5 \mu \mathrm{m} \mathrm{C18,} 100 \AA$ \&; $150 \times 4.6$ mm column). After isolation, radiolabelled conjugate was purified using Sep-Pak ${ }^{\circledR}$ Vac RC C8 cartridge (Waters, Milford, MA, USA). The cartridge was activated with $10 \mathrm{~mL}$ of $90 \% \mathrm{EtOH} /$ water followed by passing $10 \mathrm{~mL}$ Milli-Q water. Then, the radiolabelled mixture was loaded. The cartridge was rinsed by passing $10 \mathrm{~mL}$ of Milli-Q water. The radiolabelled conjugate was purified by passing $1 \mathrm{~mL}$ of $90 \% \mathrm{EtOH} /$ water and the first 6-7 drops coming from syringe connected to cartridge was collected. The purity of the labelled conjugate was determined by HPLC.

The labelling of DOTA-PEG 2 -RM26 with ${ }^{111}$ In was performed based on previously developed protocol [41]. Briefly, $92 \mu \mathrm{L}$ of $0.2 \mathrm{M}$ ammonium acetate buffer $\mathrm{pH} 5.5$ was added to aqueous solution of DOTA-PEG 2 -RM26 ( $2 \mu \mathrm{L}, 2 \mathrm{nmol}$ ) followed by addition of ${ }^{111}$ In-indium chloride solution (30-40 $\mu \mathrm{L}$, $10 \sim 20 \mathrm{MBq}$ ). The reaction mixture was incubated at $85^{\circ} \mathrm{C}$ for $30 \mathrm{~min}$. The radiochemical yield and purity were analysed using instant thin-layer chromatography (ITLC) strips using citric acid $(0.2 \mathrm{M}$, $\mathrm{pH}$ 2.0) as the running solution. 
In vitro stability of [ ${ }^{125}$ I]I-Tyr-PEG 2 -RM26 was evaluated in PBS and in presence of 100-fold molar excess of sodium iodide $(1 \mathrm{mM})$. After purification, samples of freshly labelled conjugate $(10 \mu \mathrm{L}$, $0.01 \mathrm{nmol}$ ) were mixed with $1 \mu \mathrm{L}$ of $\mathrm{NaI}$ and incubated at room temperature for $1 \mathrm{~h}$. Control samples were mixed with equal volume of PBS. The experiment was performed in duplicates. The stability of [ ${ }^{125}$ I]I-Tyr-PEG 2 -RM26 was analyzed by HPLC.

\subsection{Lipophilicity Assay: $\log P$ Measurements}

Lipophilicity was determined as the logarithm of partition coefficient, $\log P$, of the radiolabelled compound between $n$-octanol and water [42]. To determine the lipophilicity of both radioconjugates, $500 \mu \mathrm{L}$ of $n$-octanol was added to a tube containing the same volume of Milli-Q water. 1 pmol $(10 \mathrm{kBq})$ of radioconjugate was added. The mixture was vigorously vortexed for 1-2 $\mathrm{min}$ and then centrifuged. Aliquots of $100 \mu \mathrm{L}$ were taken from each phase and their radioactivity was measured by an automated gamma-counter. The partition coefficient was calculated as the average log of a ratio of the radioactivity in organic and aqueous fractions. Each measurement was repeated in triplicate.

\subsection{In Vitro Studies}

GRPR-expressing human PC cell line PC-3 and DU-145 cell lines (ATCC) were cultured in RPMI media complemented with 10\% FBS, $2 \mathrm{mM}$ L-glutamine, and PEST (penicillin $100 \mathrm{IU} / \mathrm{mL}$ ) (all from Biochrom AG, Berlin, Germany). This media is referred to as complete media in the text. In all in vitro experiments, cells were incubated in complete media. During in vitro specificity experiments, cells were detached using trypsin-EDTA solution (0.25\% trypsin, $0.02 \%$ EDTA in buffer; Biochrom AG). All experiments were performed in triplicate and $1 \times 10^{6}$ cells/dish were seeded one day before the experiment.

\subsubsection{In Vitro Binding Specificity Assay}

The in vitro binding specificity test of $\left[{ }^{125} \mathrm{I}\right] \mathrm{I}-\mathrm{Ty}-\mathrm{PEG}_{2}-\mathrm{RM} 26$ was performed on PC-3 and DU-145 cell lines. A set of three dishes containing approximately $10^{6}$ cells/dish was seeded. The cells were incubated with $1 \mathrm{nM}$ concentration of [ $\left.{ }^{125} \mathrm{I}\right] \mathrm{I}-\mathrm{Tyr}-\mathrm{PEG}_{2}-\mathrm{RM} 26$ solution for $1 \mathrm{~h}$ at $37^{\circ} \mathrm{C}$. To saturate GRPR, one set of dishes was treated with 200-fold molar excess of non-labelled peptide, NOTA-PEG ${ }_{4}-\mathrm{RM} 26$, 15 min before adding the radiolabelled compound. After washing with serum-free media, cells were detached by treatment with $1 \mathrm{~mL}$ trypsin-EDTA solution twice. Cell-associated radioactivity was measured in the gamma-counter and presented as percentage of cell-associated activity.

\subsubsection{In Vitro Competitive Binding Assay: $\mathrm{IC}_{50}$ Determination}

The in vitro competitive binding assay was performed using [ $\left.{ }^{111} \mathrm{In}\right] \mathrm{In}-\mathrm{NOTA}-\mathrm{PEG}_{4}-\mathrm{RM} 26$. The half maximal inhibitory concentration $\left(\mathrm{IC}_{50}\right)$ was determined for non-labelled Tyr-PEG $-\mathrm{RM}_{2} 6$ and DOTA-PEG $2-R M 26$ conjugates. A set of three dishes containing approximately $10^{6}$ cells/dish was used. Cell monolayers were incubated with increasing concentrations of Tyr-PEG - RM26 and DOTA-PEG $2-R M 26(0-270 \mathrm{nM})$ in the presence of [111 In]In-NOTA-PEG ${ }_{4}-\mathrm{RM} 26(1 \mathrm{nM})$ for $5 \mathrm{~h}$ at $4{ }^{\circ} \mathrm{C}$. After incubation, the cells were treated with trypsin-EDTA solution at $37{ }^{\circ} \mathrm{C}$, collected and cell-associated radioactivity was determined. The $\mathrm{IC}_{50}$ values were calculated by fitting the data by nonlinear regression using GraphPad Prism software (GraphPad Software Inc., San Diego, CA, USA).

\subsubsection{Cellular Processing Assay}

The PC-3 cells $\left(10^{6}\right.$ cells/dish) were incubated with $1 \mathrm{nM}$ of $\left.{ }^{125} \mathrm{I}\right] \mathrm{I}-\mathrm{Ty}-\mathrm{PEG}_{2}-\mathrm{RM} 26$ or $\left[{ }^{111} \mathrm{In}\right] \mathrm{In}-\mathrm{DOTA}-\mathrm{PEG}_{2}-\mathrm{RM} 26$ at $37{ }^{\circ} \mathrm{C}$ for $24 \mathrm{~h}$. At predetermined time points $(1,2,4,8,24 \mathrm{~h})$, incubation media was aspirated, cells were washed with serum-free media, and membrane-bound and internalized radioactivity were collected using the method described earlier [43]. The membrane-bound radiolabelled conjugate were removed from cells by treatment with $4 \mathrm{M}$ urea solution in a $0.1 \mathrm{M}$ 
glycine buffer, $\mathrm{pH} \mathrm{2,} \mathrm{for} 5 \mathrm{~min}$ on ice. The cell debris containing the internalized conjugate was detached by treatment with $1 \mathrm{M} \mathrm{NaOH}$. Radioactivity of samples was measured, and percentage of membrane-bound, internalized and total radioactivity was calculated. The experiments were performed in triplicate.

Additionally, PC-3 cells were incubated with $1 \mathrm{nM}$ of $\left[{ }^{125} \mathrm{I}\right] \mathrm{I}-\mathrm{Tyr}-\mathrm{PEG}_{2}-\mathrm{RM} 26$ in presence of $20 \mathrm{mM}$ sodium azide $/ 10 \mathrm{mM}$ 2-deoxyglucose at $37^{\circ} \mathrm{C}$ for $8 \mathrm{~h}$. Another set of dishes were incubated with $100 \mu \mathrm{M}$ of chloroquine diphosphate and $20 \mathrm{nM}$ of ammonium chloride in the presence of [ $\left.{ }^{125} \mathrm{I}\right] \mathrm{I}-\mathrm{Tyr}-\mathrm{PEG}_{2}-\mathrm{RM} 26$ $(1 \mathrm{nM})$. At predetermined time points $(2,4$, and $8 \mathrm{~h})$, media from a set of three dishes was removed, cells were detached by trypsin-EDTA solution, re-suspended, and radioactivity in cells was measured.

\subsection{In Vivo Studies}

Animal studies were planned and performed in agreement with EU Directive 2010/63/EU for animal experiments and Swedish national legislation concerning protection of laboratory animals. Experiments were approved by the Ethics Committee for Animal Research in Uppsala (C4/16, 26 February 2016). Biodistribution studies were performed in female BALB/C nu/nu mice purchased from Scanbur A/S (Karlslunde, Denmark). GRPR-expressing xenografts were established by subcutaneous injection of 5 $\times 10^{6} \mathrm{PC}-3$ cells/mouse in the right hind leg of mice 3 weeks before the experiment. The animals were randomized into groups of four mice for each data point. At the time of the experiment, the average animal weight was $16.3 \pm 0.9 \mathrm{~g}$. Average tumour weight was $0.09 \pm 0.07 \mathrm{~g}$.

2.5.1. Biodistribution and In Vivo binding Specificity Test of $\left[{ }^{125} \mathrm{I}\right] \mathrm{I}-\mathrm{Ty}-\mathrm{PEG}_{2}-\mathrm{RM} 26$ and [111 In]In-DOTA-PEG $2-$ RM26 in BALB/c nu/nu Mice Bearing PC-3 Prostate Cancer Xenografts

To study tumour targeting, female BALB/c nu/nu mice bearing PC-3 xenografts (4 mice per data point) were intravenously co-injected into the tail vein with totally $40 \mathrm{pmol}$ of $\left[{ }^{125} \mathrm{I}\right] \mathrm{I}-\mathrm{Tyr}-\mathrm{PEG}_{2}-\mathrm{RM} 26$ and $\left.{ }^{111} \mathrm{In}\right] \mathrm{In}-\mathrm{DOTA}-\mathrm{PEG}_{2}-\mathrm{RM} 26$ mixture $(30 \mathrm{kBq}, 100 \mu \mathrm{L}$ in PBS). Mice were euthanized followed by dislocation of their neck at $0.5 \mathrm{~h}$ after injection and blood samples were collected by heart puncture. At 3 and $24 \mathrm{~h}$ after injection, mice were euthanized by an intraperitoneal injection of anaesthetic solution ( $20 \mu \mathrm{L}$ of solution per gram of body weight: Ketalar, $10 \mathrm{mg} / \mathrm{mL}$; Rompun, $1 \mathrm{mg} / \mathrm{mL}$ ) followed by heart puncture. Salivary glands, thyroid, lung, liver, spleen, pancreas, stomach, small intestine, kidneys, tumour, muscle, and bone were collected and weighed. The organ radioactivity was measured in a gamma-counter and uptake values of organs were calculated as percentage of injected dose per gram tissue (\% ID/g). To test the in vivo binding specificity, a group of mice was co-injected with $7.5 \mathrm{nmol}$ of non-labelled peptide (NOTA-PEG 4 -RM26), and biodistribution was measured at $0.5 \mathrm{~h}$ after injection.

2.5.2. Biodistribution of [ $\left.{ }^{125} \mathrm{I}\right] \mathrm{I}-\mathrm{Tyr}-\mathrm{PEG}_{2}-\mathrm{RM} 26$ in NMRI Mice by Co-Injection of Phosphoramidon (PA) as In Vivo Stabilizer

Two groups of 4 mice were used for this experiment. Biodistribution of [ $\left.{ }^{125} \mathrm{I}\right] \mathrm{I}-\mathrm{Tyr}-\mathrm{PEG}_{2}-\mathrm{RM} 26$ was evaluated in female NMRI mice (weight: $29.6 \pm 1.7 \mathrm{~g}$ ). Non-tumour bearing mice as a control group were injected with 40 pmol of $\left[{ }^{125} \mathrm{I}\right] \mathrm{I}-\mathrm{Tyr}-\mathrm{PEG}_{2}-\mathrm{RM} 26(30 \mathrm{kBq}, 100 \mu \mathrm{L}$ in PBS) into the tail vein. Another group of mice was injected with same activity by co-injection of PA ( $15 \mu \mathrm{L}$ of $20 \mathrm{mg} / \mathrm{mL}$ stock solution, $300 \mu \mathrm{g}$ ). After $0.5 \mathrm{~h}$, mice were euthanized by dislocation of their neck, and blood samples were collected. Salivary glands, thyroid, lung, liver, spleen, pancreas, stomach, small intestine, kidneys, tumour, muscle, and bone were collected and weighed. The organ radioactivity was measured in a gamma-counter and uptake values of organs were calculated as percentage injected dose per gram tissue $(\% \mathrm{ID} / \mathrm{g})$. 


\subsection{Statistical Analysis}

Statistical treatment and linear regression analysis were performed using GraphPad Prism software version 5.00 for Windows, GraphPad Software, San Diego California. A two-tailed unpaired $t$-test was used for comparison of the two sets of data. The difference was considered as significant when $p$ value was less than 0.05 .

\section{Results}

\subsection{Peptide Synthesis and Characterization}

Tyr-PEG - RM26 was synthesized as previously described and purified by preparative HPLC, generating in $1.7 \mathrm{mg}$ of desired product, corresponding to a total yield of $6.0 \%$ (based on the initial loading of the resin). After LC-MS analysis, purity was determined, based on the $280 \mathrm{~nm}$ trace, to be over $95 \%$ (Figure $2 a$ ) and the $\mathrm{m} / \mathrm{z}$ value found was in accordance with expected value $\left([\mathrm{M}+2 \mathrm{H}]^{2+} \mathrm{m} / \mathrm{z}\right.$ $=711.4$ ) (Figure 2b). The conjugate was freeze dried and used for in vitro and in vivo experiments. Figure 1 showed the structural formula of both Tyr-PEG $2-R M 26$ and DOTA-PEG $2-R M 26$.

(a)

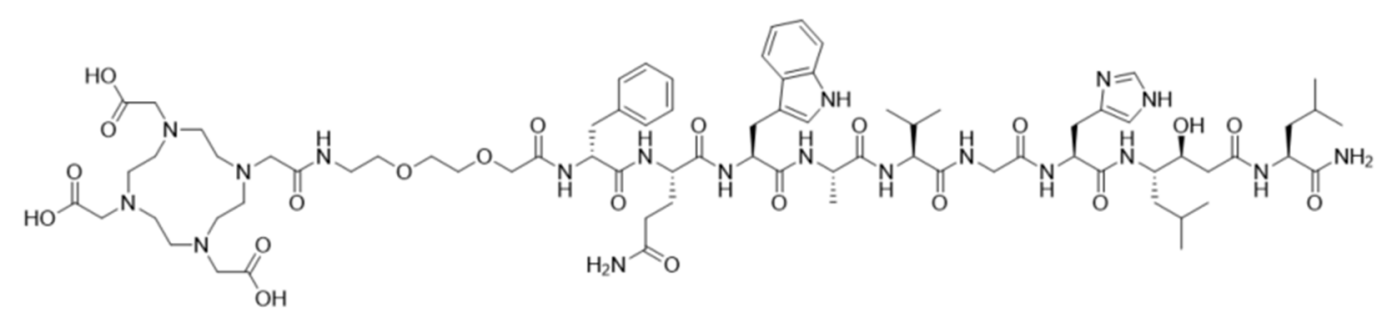

(b)

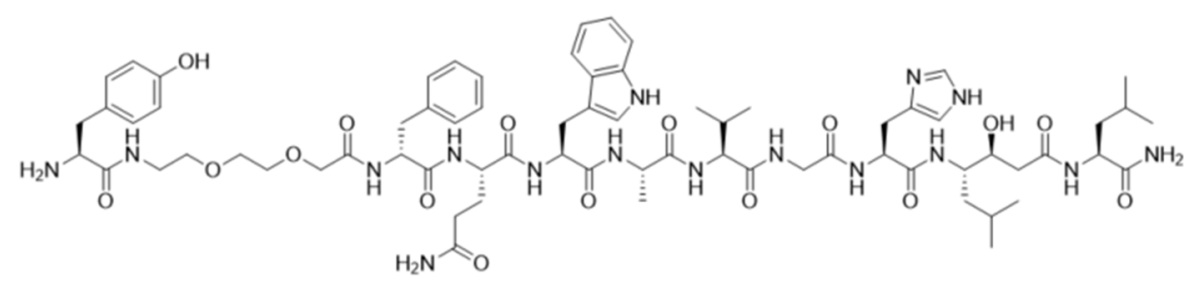

Figure 1. Structural formula of (a) DOTA-PEG 2 -[D-Phe $\left.{ }^{6}, \mathrm{Sta}^{13}, \mathrm{Leu}^{14}\right]$ bombesin[6-14] (DOTA-PEG 2 -RM26); (b) Tyrosine-PEG 2 -[D-Phe ${ }^{6}$, Sta $^{13}$, Leu $\left.{ }^{14}\right]$ bombesin[6-14] (Tyr-PEG 2 -RM26). 

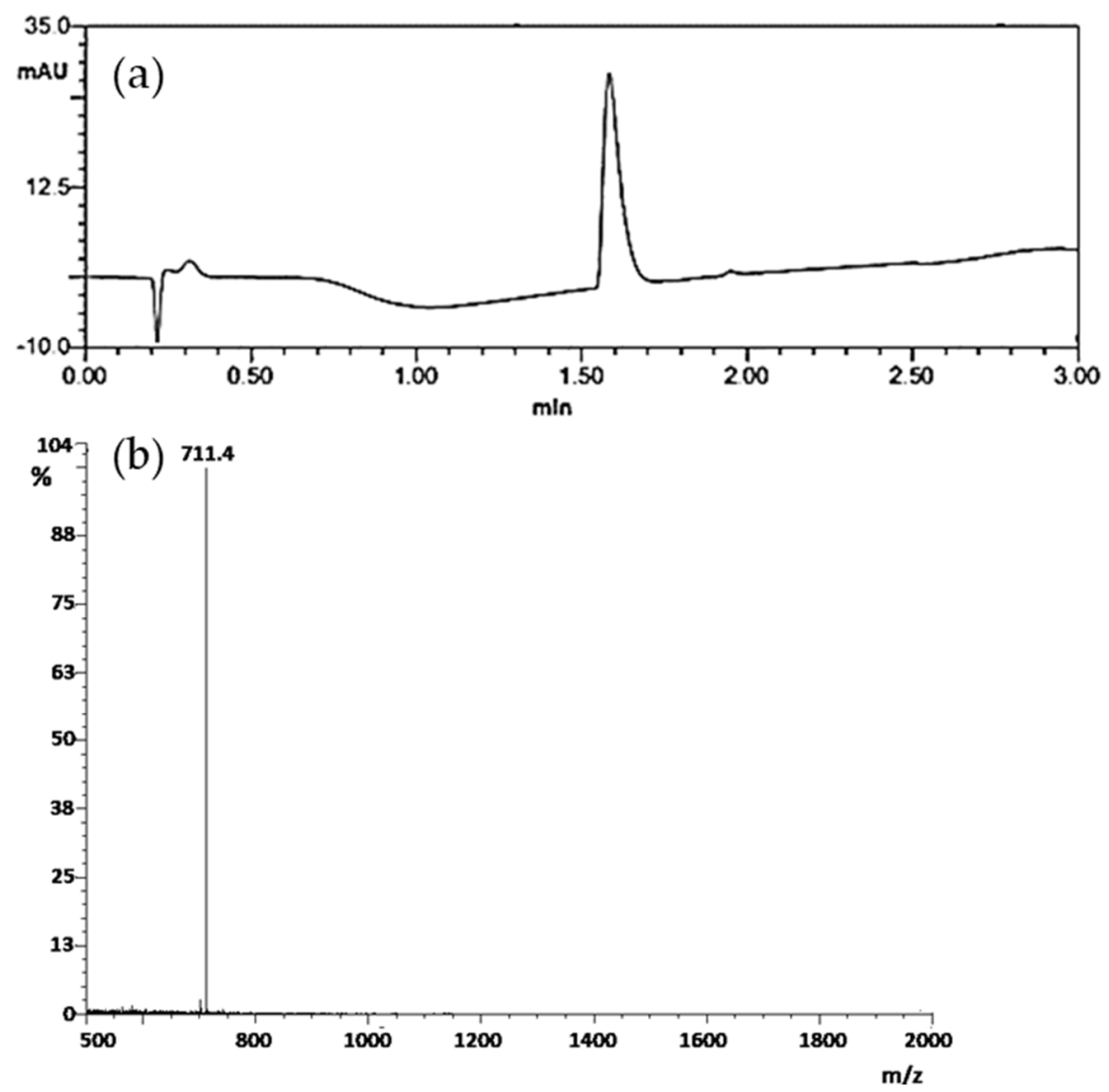

Figure 2. (a) High-performance liquid chromatography (HPLC) chromatogram of Tyr-PEG $2-\mathrm{RM}_{2} 6$ at $280 \mathrm{~nm}$ and (b) mass spectrum of Tyr-PEG $2-\mathrm{RM}_{2} 6$.

\subsection{Radiolabelling and In Vitro Stability Test}

The radiolabelling of Tyr-PEG $-\mathrm{RM}_{2} 6$ with ${ }^{125} \mathrm{I}$ was performed at room temperature followed by HPLC analysis and preparative separation. The radiochemical yield was $77 \pm 7 \%$ as determined using radio-HPLC. After purification using Sep-Pak C 8 cartridge, the radiochemical purity was $95 \pm 2 \%$. The results of the in vitro stability test demonstrated that the radiolabelled conjugate was stable in PBS (95 $\pm 1 \%)$ and also in presence of excess amount of $1 \mathrm{mM} \mathrm{NaI}(92 \pm 3 \%)$ after $1 \mathrm{~h}$ incubation at room temperature.

Labelling of DOTA-PEG 2 -RM26 with ${ }^{111}$ In resulted in radiochemical purity of $100 \%$, and $\left.{ }^{1111} \mathrm{In}\right] \mathrm{In}-\mathrm{DOTA}-\mathrm{PEG}_{2}-\mathrm{RM} 26$ was used in biological experiments without additional purification.

\subsection{Lipophilicity Assay: $\log P$}

The lipophilicity of both radiolabelled conjugates was evaluated using "shake-flask"- method. Partition coefficient, $\log P$ of $\left[{ }^{125} \mathrm{I}\right] \mathrm{I}-\mathrm{Ty}-\mathrm{PEG}_{2}-\mathrm{RM} 26$ and [ [111 In]In-DOTA-PEG $2-\mathrm{RM}_{2} 6$ was $1.0 \pm 0.1$ and $-2.6 \pm 0.4$, respectively.

\subsection{In Vitro Studies}

\subsubsection{In Vitro Binding Specificity Assay}

In vitro binding specificity test demonstrated that binding of [ $\left.{ }^{125} \mathrm{I}\right] \mathrm{I}-\mathrm{Ty}-\mathrm{PEG}_{2}-\mathrm{RM} 26$ to PC-3 and DU-145 cells is receptor mediated. Pre-saturation of the cells with non-labelled NOTA-PEG 4 -RM26 significantly $(p<0.05)$ decreased the cell binding of the radiolabelled compounds (Figure 3). Specific binding to DU-145 cells was much lower than specific binding to PC-3 cells. 


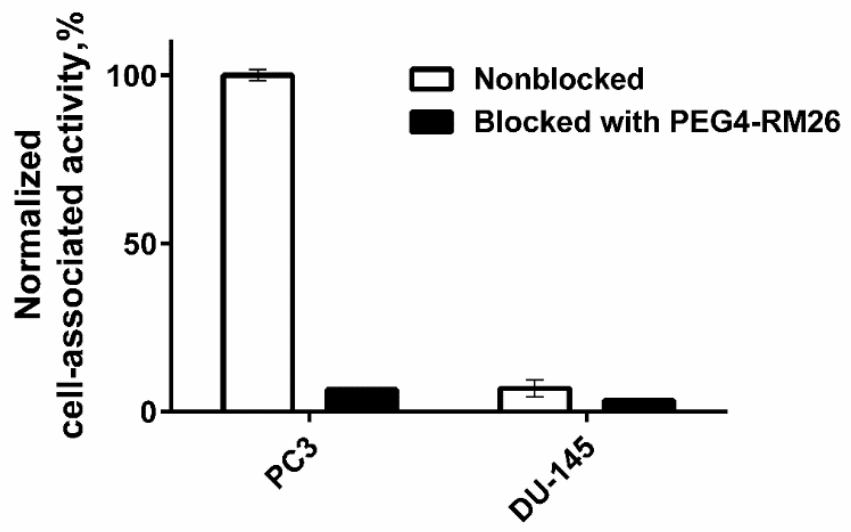

Figure 3. In vitro specificity of $\left[{ }^{125} \mathrm{I}\right] \mathrm{I}-\mathrm{Ty}-\mathrm{PEG}_{2}-\mathrm{RM} 26$ to PC-3 and DU-145 cells. Radiolabelled conjugate was added to cultured cells at a concentration of $1 \mathrm{nM}$. One set of culture dishes was pre-saturated with a 200 -fold molar excess of non-labelled NOTA-PEG 4 -RM26 before incubation with the labelled conjugate.

\subsubsection{In Vitro Competitive Binding Assay: $\mathrm{IC}_{50}$ Determination}

Binding properties of Tyr- $\mathrm{PEG}_{2}-\mathrm{RM} 26$ and DOTA-PEG $-\mathrm{RM} 26$ to PC-3 cells were compared

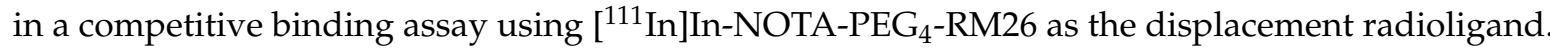
The $\mathrm{IC}_{50}$ values for Tyr-PEG $-\mathrm{RM} 26$ and DOTA-PEG $2-\mathrm{RM} 26$ were determined to be $1.7 \pm 0.3$ and $3.3 \pm 0.5 \mathrm{nM}$, respectively (Figure 4 ).

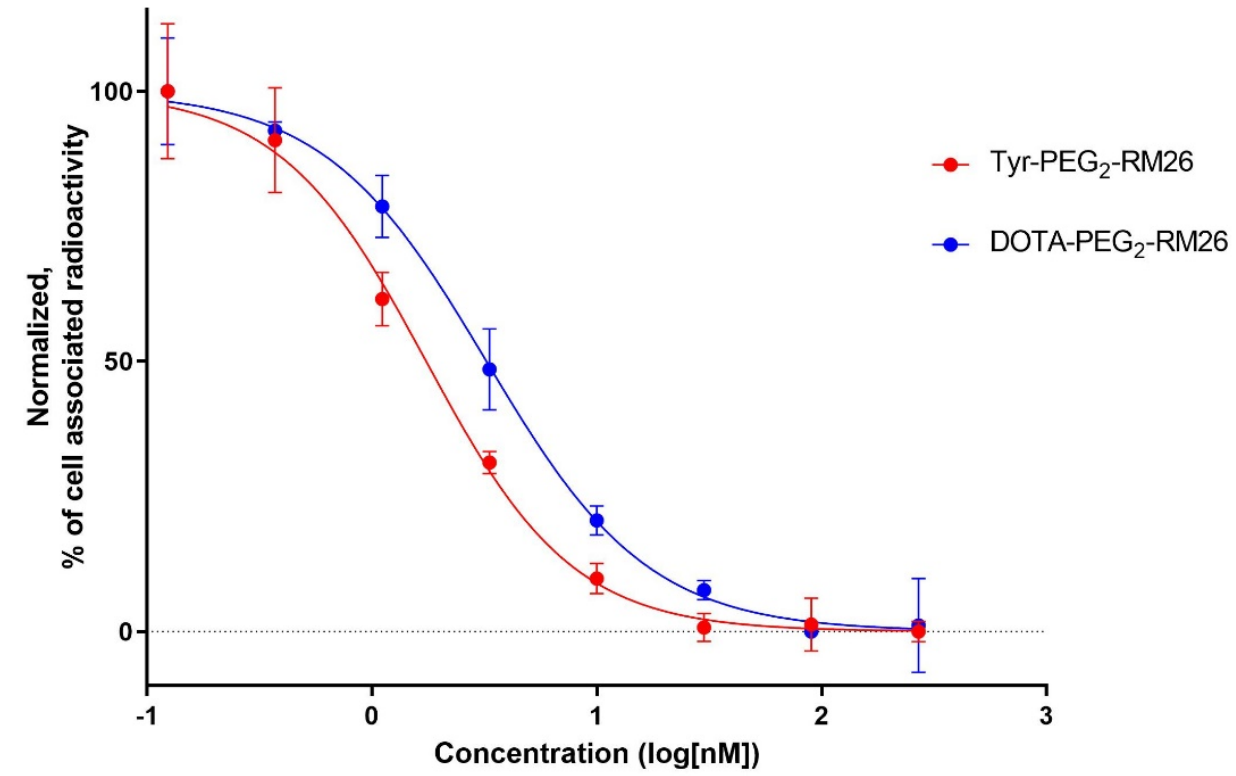

Figure 4. Inhibition of $\left[{ }^{111} \mathrm{In}\right] \mathrm{In}-\mathrm{NOTA}-\mathrm{PEG}_{4}-\mathrm{RM} 26$ binding to PC-3 cells with X-PEG $2-\mathrm{RM} 26$ $(\mathrm{X}=$ tyrosine, DOTA). Data are presented as the mean value of three dishes $\pm \mathrm{SD}$.

\subsubsection{Cellular Processing Assay}

Data concerning cellular processing of [ $\left.{ }^{125} \mathrm{I}\right] \mathrm{I}-\mathrm{Ty}-\mathrm{PEG}_{2}-\mathrm{RM} 26$ and [111 In]In-DOTA-PEG $2-\mathrm{RM}_{2} 6$ by PC -3 cells are presented in Figure 5. Cellular processing of [ $\left.{ }^{125} \mathrm{I}\right] \mathrm{I}-\mathrm{Ty}-\mathrm{PEG}_{2}-\mathrm{RM} 26$ by PC-3 cell line was characterized by fast binding and quite fast internalization during the first hour of incubation followed by a decreased cell-associated activity with time. The rapid binding of [ $\left.{ }^{111} \mathrm{In}\right] \mathrm{In}-\mathrm{DOTA}-\mathrm{PEG}_{2}-\mathrm{RM} 26$ to PC-3 cells was accompanied by slower internalization, reaching $14 \%$ of cell-associated radioactivity after $24 \mathrm{~h}$ incubation at $37^{\circ} \mathrm{C}$. 
(a)

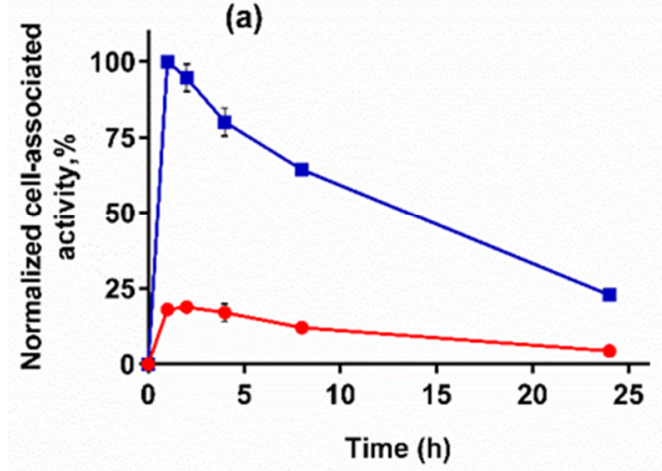

(b)

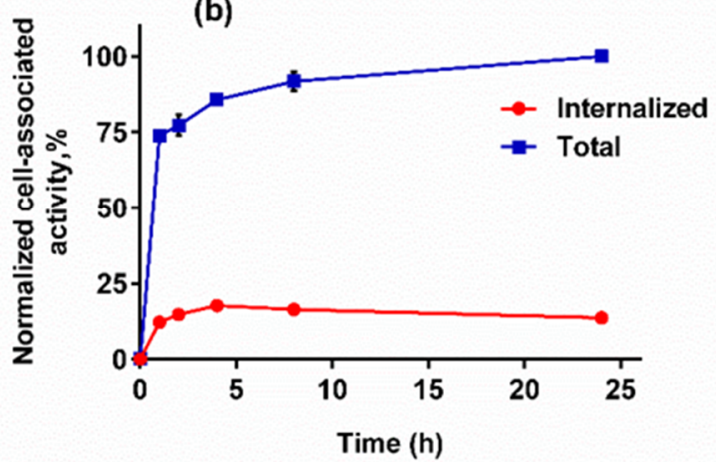

Figure 5. Cellular processing of (a) $\left[{ }^{125} \mathrm{I}\right] \mathrm{I}-\mathrm{Ty}-\mathrm{PEG}_{2}-\mathrm{RM} 26$ and (b) $\left[{ }^{111} \mathrm{In}\right] \mathrm{In}-\mathrm{DOTA}-\mathrm{PEG}_{2}-\mathrm{RM} 26$ on PC-3. Data are presented as the mean values of three dishes \pm SD. Not all error bars are visible due to the small standard deviations.

Figure 6 shows the effect of the lysosomotropic weak bases, chloroquine, and ammonium chloride, on amount of cell-bound activity of $\left[{ }^{125} \mathrm{I}\right] \mathrm{I}-\mathrm{Ty}$ - $-\mathrm{PEG}_{2}-\mathrm{RM}_{2} 6$ over time. Cell-bound activity and retention of $\left[{ }^{125} \mathrm{I}\right] \mathrm{I}-\mathrm{Tyr}-\mathrm{PEG}_{2}-\mathrm{RM} 26$ on PC-3 cells in the presence of these two weak bases were considerably higher compared to control. Cell-associated activity for the cell treated with sodium azid, that should inhibit synthesis of the new receptors, was similar to the controls.

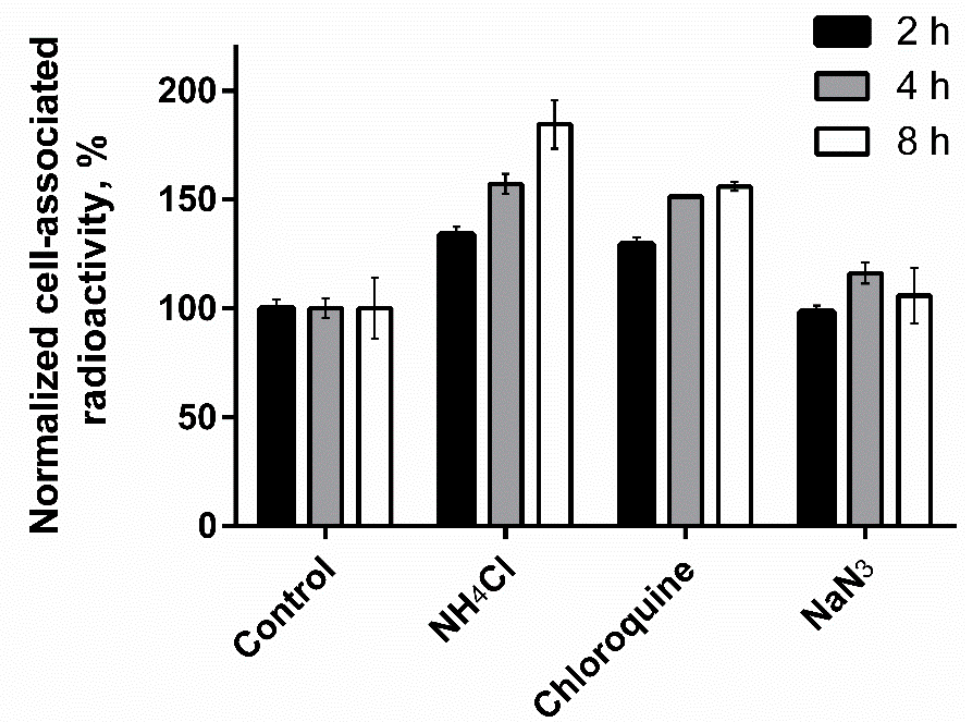

Figure 6. Normalized cell-associated radioactivity of [ $\left.{ }^{125} \mathrm{I}\right] \mathrm{I}-\mathrm{Ty}-\mathrm{PEG}_{2}-\mathrm{RM} 26$ in the presence $20 \mathrm{mM}$ sodium azide/10 mM 2-deoxyglucose, $100 \mu \mathrm{M}$ Chloroquine, $20 \mathrm{mM}$ ammonium chloride by PC-3 cells during continuous incubation at $37^{\circ} \mathrm{C}$. One set of culture dishes was tested as control.

\subsection{In Vivo Studies}

3.5.1. Biodistribution and In Vivo Binding Specificity Test of $\left[{ }^{125} \mathrm{I}\right] \mathrm{I}-\mathrm{Tyr}-\mathrm{PEG}_{2}-\mathrm{RM} 26$ and [111 In]In-DOTA-PEG $2-$ RM26 in BALB/c nu/nu Mice Bearing PC-3 Prostate Cancer Xenografts

In vivo specificity of $\left[{ }^{125} \mathrm{I}\right] \mathrm{I}-\mathrm{Ty}-\mathrm{PEG}_{2}-\mathrm{RM} 26$ and $\left[{ }^{111} \mathrm{In}\right] \mathrm{In}-\mathrm{DOTA}-\mathrm{PEG}_{2}-\mathrm{RM} 26$ binding to GRPR-expressing PC-3 in tumour xenografts was evaluated by saturation of receptors using a co-injection of non-labelled peptide (NOTA-PEG 4 -RM26) (Figure 7) at $0.5 \mathrm{~h}$ after injection. Uptake of $\left[{ }^{125} \mathrm{I}\right] \mathrm{I}-\mathrm{Tyr}-\mathrm{PEG}_{2}-\mathrm{RM} 26$ in pancreas and tumour in the blocked group was significantly $(p<0.05)$ reduced compared to non-blocked group. For [111 In]In-DOTA-PEG 2 -RM26, significant $(p<0.05)$ reduction of uptake for lung, pancreas, stomach, small intestine and tumour in the blocked group compared to 
non-blocked group was observed, indicating GRPR-specific accumulation of both radioconjugates. The blocking effect was more pronounced for [ $\left.{ }^{111} \mathrm{In}\right] \mathrm{In}-\mathrm{DOTA}-\mathrm{PEG}_{2}-\mathrm{RM} 26$.
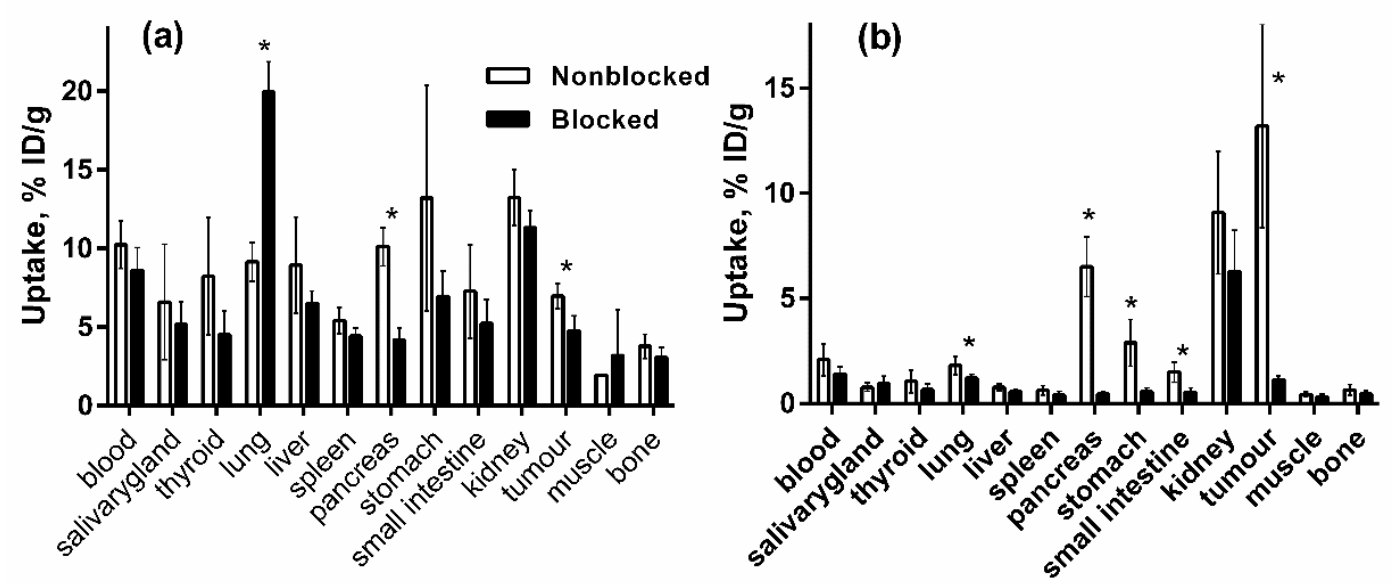

Figure 7. In vivo specificity of (a) [ $\left.{ }^{125} \mathrm{I}\right] \mathrm{I}-\mathrm{Ty} r-\mathrm{PEG}_{2}-\mathrm{RM} 26$ and (b) [ $\left.{ }^{111} \mathrm{In}\right] \mathrm{In}-\mathrm{DOTA}-\mathrm{PEG}_{2}-\mathrm{RM} 26$ in PC-3 tumour xenograft bearing $\mathrm{BALB} / \mathrm{C} \mathrm{nu} / \mathrm{nu}$ at $30 \mathrm{~min}$ after injection. Blocking was performed by GRPR saturation with co-injection of non-labelled NOTA-PEG 4 -RM26. Asterisk $\left(^{*}\right)$ marks significant $(p<0.05)$ difference. Data are presented as a mean $\pm \mathrm{SD} ; n=4$. Error bars might not be seen because they are smaller than the symbols.

Biodistribution of [ $\left.{ }^{125} \mathrm{I}\right] \mathrm{I}-\mathrm{Tyr}-\mathrm{PEG}_{2}-\mathrm{RM} 26$ and [ $\left.{ }^{111} \mathrm{In}\right] \mathrm{In}-\mathrm{DOTA} \mathrm{PEG}_{2}-\mathrm{RM} 26$ in PC-3-xenografted mice were studied in dual label study at $0.5,3$ and $24 \mathrm{~h}$ after injection and results are presented in Table 1 . Data obtained for [ ${ }^{111} \mathrm{In}$ ]In-DOTA-PEG - -RM26 are in good agreement with previously published results [40]. Clearance of $\left[{ }^{125} \mathrm{I}\right] \mathrm{I}-\mathrm{Ty}-\mathrm{PEG}_{2}-\mathrm{RM} 26$ from blood was remarkably slower than clearance of $\left[{ }^{111} \mathrm{In}\right] \mathrm{In}-\mathrm{DOTA}-\mathrm{PEG}_{2}-\mathrm{RM} 26$. The activity accumulation of $\left[{ }^{125} \mathrm{I}\right] \mathrm{I}-\mathrm{Tyr}-\mathrm{PEG}_{2}-\mathrm{RM} 26$ in all normal organs was significantly $(p<0.05)$ higher than accumulation of $\left[{ }^{111}\right.$ In]In-DOTA-PEG 2 -RM26 at all three time points. High uptake was observed for the receptor-positive organs for both radioconjugates. Tumour uptake of [ $\left.{ }^{111} \mathrm{In}\right] \mathrm{In}-\mathrm{DOTA}-\mathrm{PEG}_{2}-\mathrm{RM} 26$ was significantly $(p<0.05)$ higher than [ $\left.{ }^{125} \mathrm{I}\right] \mathrm{I}-\mathrm{Tyr}-\mathrm{PEG}_{2}-\mathrm{RM} 26$, resulting in significantly higher tumour-to-organ ratio (Table 2). Moreover, the washout rate of [111 In]In-DOTA-PEG 2 -RM26 from the target-expressing normal tissues was higher than that from the tumour, leading to increasing tumour-to-organ ratios over time. 
Table 1. Biodistribution of [ $\left.{ }^{125} \mathrm{I}\right] \mathrm{I}-\mathrm{Ty}-\mathrm{PEG}_{2}-\mathrm{RM} 26$ and $\left[{ }^{111} \mathrm{In}\right] \mathrm{In}-\mathrm{DOTA}_{\mathrm{PEG}}-\mathrm{RM} 26$ in GRPR-expressing PC-3 tumour xenografted female BALB/C nu/nu mice at three time points (total injected mass of $40 \mathrm{pmol})$. Data are presented as the mean percentage of injected dose per gram tissue $(\% \mathrm{ID} / \mathrm{g} ; \mathrm{Mean} \pm \mathrm{SD} ; n=4)$, NM stands for non-measureable.

\begin{tabular}{|c|c|c|c|c|c|c|}
\hline & \multicolumn{6}{|c|}{ Uptake, \% ID/g } \\
\hline & \multicolumn{2}{|r|}{$0.5 \mathrm{~h}$} & \multicolumn{2}{|r|}{$3 \mathrm{~h}$} & \multicolumn{2}{|c|}{$24 \mathrm{~h}$} \\
\hline & {$\left[{ }^{125} \mathrm{I}\right] \mathrm{I}-\mathrm{Tyr}-\mathrm{PEG}_{2}-\mathrm{RM} 26$} & [111 In]In-DOTA-PEG 2 -RM26 & $\left.{ }^{[25} \mathrm{I}\right] \mathrm{I}-\mathrm{Tyr}-\mathrm{PEG}_{2}-\mathrm{RM} 26$ & [111 In]In-DOTA-PEG ${ }_{2}-\mathrm{RM} 26$ & {$\left[{ }^{125} \mathrm{I}\right] \mathrm{I}-\mathrm{Tyr}-\mathrm{PEG}_{2}-\mathrm{RM} 26$} & [111 In]In-DOTA-PEG ${ }_{2}-\mathrm{RM} 26$ \\
\hline blood & $10.2 \pm 1.5^{\mathrm{a}, \mathrm{d}, \mathrm{e}}$ & $2.1 \pm 0.8^{\mathrm{a}, \mathrm{g}, \mathrm{h}}$ & $2.9 \pm 1.5^{\mathrm{b}, \mathrm{d}, \mathrm{f}}$ & $0.03 \pm 0.00^{\mathrm{b}, \mathrm{g}, \mathrm{i}}$ & $0.02 \pm 0.00^{c, e, f}$ & $0.006 \pm 0.002 \mathrm{c}, \mathrm{h}, \mathrm{i}$ \\
\hline salivary gland & $6.6 \pm 3.7^{\mathrm{a}, \mathrm{d}}$ & $0.8 \pm 0.2^{\mathrm{a}, \mathrm{g}}$ & $2.0 \pm 1.2^{\mathrm{b}, \mathrm{d}}$ & $0.07 \pm 0.02^{\mathrm{b}, \mathrm{g}}$ & $\mathrm{NM}$ & $\mathrm{NM}$ \\
\hline thyroid & $8.2 \pm 3.7^{\mathrm{a}, \mathrm{d}}$ & $1.1 \pm 0.5^{\mathrm{a}, \mathrm{g}}$ & $2.2 \pm 1.6^{\mathrm{b}, \mathrm{d}}$ & $0.1 \pm 0.0^{b, g}$ & $\mathrm{NM}$ & NM \\
\hline lung & $9.1 \pm 1.2^{\mathrm{a}, \mathrm{d}}$ & $1.8 \pm 0.4^{\mathrm{a}, \mathrm{g}}$ & $3.5 \pm 1.4^{\mathrm{b}, \mathrm{d}, \mathrm{f}}$ & $0.1 \pm 0.0^{\mathrm{b}, \mathrm{g}}$ & $0.2 \pm 0.1^{\mathrm{f}}$ & NM \\
\hline liver & $8.9 \pm 3.1$ a,d,e & $0.8 \pm 0.2^{\mathrm{a}, \mathrm{g}, \mathrm{h}}$ & $2.6 \pm 1.1^{\mathrm{b}, \mathrm{d}, \mathrm{f}}$ & $0.2 \pm 0.0^{\mathrm{b}, \mathrm{g}, \mathrm{i}}$ & $0.2 \pm 0.0^{\mathrm{c}, \mathrm{e}, \mathrm{f}}$ & $0.1 \pm 0.0^{\mathrm{c}, \mathrm{h}, \mathrm{i}}$ \\
\hline spleen & $5.4 \pm 0.8^{\mathrm{a}, \mathrm{d}}$ & $0.6 \pm 0.2^{a, g}$ & $2.0 \pm 0.8^{\mathrm{b}, \mathrm{d}}$ & $0.1 \pm 0.0^{\mathrm{b}, \mathrm{g}}$ & NM & NM \\
\hline pancreas & $10.1 \pm 1.2^{\mathrm{a}, \mathrm{d}}$ & $6.5 \pm 1.4^{\mathrm{a}, \mathrm{g}}$ & $2.3 \pm 0.6^{b, d}$ & $0.2 \pm 0.0^{b, g}$ & $\mathrm{NM}$ & NM \\
\hline stomach & $13.2 \pm 7.2^{\mathrm{a}, \mathrm{d}}$ & $2.9 \pm 1.1^{\mathrm{a}, \mathrm{g}}$ & $4.6 \pm 2.7 \mathrm{~b}, \mathrm{~d}, \mathrm{f}$ & $0.4 \pm 0.1^{\mathrm{b}, \mathrm{g}, \mathrm{h}}$ & $0.1 \pm 0.0^{\mathrm{f}}$ & NM \\
\hline small intestine & $7.3 \pm 3.0^{\mathrm{a}, \mathrm{d}}$ & $1.5 \pm 0.5^{\mathrm{a}, \mathrm{g}}$ & $1.8 \pm 0.7^{\mathrm{b}, \mathrm{d}}$ & $0.2 \pm 0.1^{b, g}$ & NM & NM \\
\hline kidney & $13.2 \pm 1.8^{\mathrm{d}, \mathrm{e}}$ & $9.1 \pm 2.9 \mathrm{~g}, \mathrm{~h}$ & $6.1 \pm 1.1^{\mathrm{b}, \mathrm{d}}$ & $2.4 \pm 0.3^{b, f, g, i}$ & $1.5 \pm 0.3^{c, e, f}$ & $0.8 \pm 0.2^{\mathrm{c}, \mathrm{h}, \mathrm{i}}$ \\
\hline tumour & $7.0 \pm 0.8^{\mathrm{a}, \mathrm{d}}$ & $13.2 \pm 4.8^{\mathrm{a}, \mathrm{h}}$ & $2.1 \pm 0.8^{\mathrm{b}, \mathrm{d}}$ & $9.6 \pm 0.6^{\mathrm{b}, \mathrm{i}}$ & $\mathrm{NM}$ & $3.6 \pm 1.3^{\mathrm{h}, \mathrm{i}}$ \\
\hline muscle & $2.0 \pm 0.0^{\mathrm{a}, \mathrm{d}}$ & $0.4 \pm 0.1^{\mathrm{a}, \mathrm{g}}$ & $0.6 \pm 0.3^{b, d}$ & $0.02 \pm 0.00^{\mathrm{b}, \mathrm{g}}$ & NM & NM \\
\hline bone & $3.8 \pm 0.8^{\mathrm{a}, \mathrm{d}, \mathrm{h}}$ & $0.6 \pm 0.3^{a}, g$ & $1.1 \pm 0.5^{b, d}$ & $0.05 \pm 0.02^{b, g}$ & NM & NM \\
\hline
\end{tabular}

a significant difference $(p<0.05)$ between [ ${ }^{125}$ I]I-Tyr-PEG 2 -RM26 and [ $\left.{ }^{111} \mathrm{In}\right] \mathrm{In}-\mathrm{DOTA}-\mathrm{PEG}_{2}$-RM26 at $0.5 \mathrm{~h}$ after injection; ${ }^{\mathrm{b}}$ significant difference $(p<0.05)$ between $\left.{ }^{125} \mathrm{I}\right] \mathrm{I}-\mathrm{Tyr}-\mathrm{PEG}{ }_{2}$-RM26 and [111 In]In-DOTA-PEG - -RM26 at $3 \mathrm{~h}$ after injection; ${ }^{\mathrm{c}}$ significant difference $(p<0.05)$ between $\left.{ }^{125} \mathrm{I}\right] \mathrm{I}-\mathrm{Tyr}-\mathrm{PEG}_{2}-\mathrm{RM}_{26}$ and [111 In]In-DOTA-PEG $_{2}$-RM26 at $24 \mathrm{~h}$ after injection; ${ }^{\mathrm{d}}$ significant difference $(p<0.05)$ between $0.5 \mathrm{~h}^{125} \mathrm{I}$ and $3 \mathrm{~h}^{125} \mathrm{I}$; ${ }^{\mathrm{e}}$ significant difference $(p<0.05)$ between $0.5 \mathrm{~h}{ }^{125} \mathrm{I}$ and $24 \mathrm{~h}^{125} \mathrm{I}$; ${ }^{\mathrm{f}}$ significant difference $(p<0.05)$ between $3 \mathrm{~h}^{125} \mathrm{I}$ and $24 \mathrm{~h}{ }^{125} \mathrm{I}$; $\mathrm{g}$ significant difference $(p<0.05)$ between $0.5 \mathrm{~h}^{111} \mathrm{In}$ and $3 \mathrm{~h}^{111} \mathrm{In}$; ${ }^{\mathrm{h}}$ significant difference $(p<0.05)$ between $0.5 \mathrm{~h}^{111}$ In and $24 \mathrm{~h}^{111}$ In; ${ }^{\mathrm{i}}$ significant difference $(p<0.05)$ between $3 \mathrm{~h}{ }^{111}$ In and significant 
Table 2. Tumour-to-organ ratios of [ $\left.{ }^{125} \mathrm{I}\right] \mathrm{I}-\mathrm{Tyr}-\mathrm{PEG}_{2}-\mathrm{RM} 26$ and $\left[{ }^{111} \mathrm{In}\right] \mathrm{In}-\mathrm{DOTA}-\mathrm{PEG}_{2}-\mathrm{RM} 26$ in BALB/C nu/nu mice bearing GRPR-expressing PC-3 tumour xenograft at $0.5,3$ and $24 \mathrm{~h}$ after injection; (Mean $\pm \mathrm{SD} ; n=4$ ), NM stands for non-measureable.

\begin{tabular}{|c|c|c|c|c|c|c|}
\hline & \multicolumn{6}{|c|}{ Tumor-to-Organ Ratio } \\
\hline & \multicolumn{2}{|r|}{$0.5 \mathrm{~h}$} & \multicolumn{2}{|r|}{$3 \mathrm{~h}$} & \multicolumn{2}{|c|}{$24 \mathrm{~h}$} \\
\hline & {$\left[{ }^{125} \mathrm{I}\right] \mathrm{I}-\mathrm{Tyr}-\mathrm{PEG}_{2}-\mathrm{RM} 26$} & [111 In]In-DOTA-PEG 2 -RM26 & [125I]I-Tyr-PEG 2 -RM26 & [111 In]In-DOTA-PEG $2-R M 26$ & [125I]I-Tyr-PEG 2 -RM26 & [111 In]In-DOTA-PEG 2 -RM26 \\
\hline blood & $0.7 \pm 0.0^{\mathrm{a}, \mathrm{e}}$ & $6.3 \pm 1.1^{\mathrm{a}, \mathrm{g}, \mathrm{h}}$ & $0.8 \pm 0.1^{\mathrm{b}, \mathrm{f}}$ & $373 \pm 47^{b, g, i}$ & $6 \pm 4^{\mathrm{c}, \mathrm{e}, \mathrm{f}}$ & $672 \pm 41^{c, h, i}$ \\
\hline salivary gland & $1.3 \pm 0.6^{\mathrm{a}}$ & $16.5 \pm 3.6^{\mathrm{a}, \mathrm{g}}$ & $1.2 \pm 0.3^{b}$ & $146 \pm 36^{\mathrm{b}, \mathrm{g}}$ & NM & NM \\
\hline thyroid & $1.0 \pm 0.5^{\mathrm{a}}$ & $14.6 \pm 5.8^{\mathrm{a}, \mathrm{g}}$ & $1.2 \pm 0.6^{b}$ & $105 \pm 40^{\mathrm{b}, \mathrm{g}}$ & NM & NM \\
\hline lung & $0.8 \pm 0.0^{\mathrm{a}, \mathrm{d}}$ & $7.1 \pm 1.8^{\mathrm{a}, \mathrm{g}}$ & $0.6 \pm 0.1^{b, d}$ & $123 \pm 7^{\mathrm{b}, \mathrm{g}}$ & $1.0 \pm 0.6$ & NM \\
\hline liver & $0.8 \pm 0.2^{\mathrm{a}}$ & $16.4 \pm 3.8^{\mathrm{a}, \mathrm{g}, \mathrm{h}}$ & $0.8 \pm 0.2^{b}$ & $61 \pm 3^{b, g, i}$ & $0.6 \pm 0.5^{c}$ & $45 \pm 8^{\mathrm{c}, \mathrm{h}, \mathrm{i}}$ \\
\hline spleen & $1.30 \pm 0.2^{\mathrm{a}, \mathrm{d}}$ & $20.8 \pm 2.5^{\mathrm{a}, \mathrm{g}}$ & $1.1 \pm 0.1^{\mathrm{b}, \mathrm{d}}$ & $119 \pm 7^{b, g}$ & NM & NM \\
\hline pancreas & $0.7 \pm 0.1^{\mathrm{a}}$ & $2.0 \pm 0.4^{\mathrm{a}, \mathrm{g}}$ & $0.9 \pm 0.1^{b}$ & $50 \pm 6^{\mathrm{b}, \mathrm{g}}$ & NM & NM \\
\hline stomach & $0.6 \pm 0.2^{\mathrm{a}}$ & $4.6 \pm 1.1^{\mathrm{a}, \mathrm{g}}$ & $0.5 \pm 0.1^{b}$ & $27 \pm 6^{b, g}$ & NM & NM \\
\hline small intestine & $1.1 \pm 0.6^{\mathrm{a}}$ & $9.0 \pm 3.3^{a, g}$ & $1.3 \pm 0.4^{b}$ & $68 \pm 35^{b, g}$ & NM & NM \\
\hline kidney & $0.5 \pm 0.0^{\mathrm{a}, \mathrm{d}, \mathrm{e}}$ & $1.4 \pm 0.3^{\mathrm{a}, \mathrm{g}, \mathrm{h}}$ & $0.3 \pm 0.1 \mathrm{~b}, \mathrm{~d}, \mathrm{f}$ & $4 \pm 0^{\mathrm{b}, \mathrm{g}}$ & $0.10 \pm 0.0^{c, e, f, i}$ & $5 \pm 1^{c, h, i}$ \\
\hline muscle & $3.6 \pm 0.4^{\mathrm{a}}$ & $29.9 \pm 6.6^{a, g}$ & $3.7 \pm 0.6^{b}$ & $428 \pm 41^{b, g}$ & NM & NM \\
\hline bone & $1.9 \pm 0.2^{\mathrm{a}}$ & $22.8 \pm 12.8^{\mathrm{a}, \mathrm{g}}$ & $1.9 \pm 0.3^{b}$ & $221 \pm 110^{b, g}$ & NM & NM \\
\hline
\end{tabular}

a significant difference $(p<0.05)$ between [ ${ }^{125}$ I]I-Tyr-PEG 2 -RM26 and [111 In]In-DOTA-PEG 2 -RM26 at $0.5 \mathrm{~h}$ after injection; ${ }^{\mathrm{b}}$ significant difference $(p<0.05)$ between $\left[{ }^{125} \mathrm{I}\right] \mathrm{I}-\mathrm{Tyr}-\mathrm{PEG}{ }_{2}$-RM26 and [111 In]In-DOTA-PEG 2 -RM26 at $3 \mathrm{~h}$ after injection; ${ }^{\mathrm{c}}$ significant difference $(p<0.05)$ between $\left.{ }^{125} \mathrm{I}\right] \mathrm{I}-\mathrm{Tyr}-\mathrm{PEG}_{2}-\mathrm{RM}_{26}$ and $\left[{ }^{111}\right.$ In]In-DOTA-PEG 2 -RM26 at $24 \mathrm{~h}$ after injection; ${ }^{\mathrm{d}}$ significant difference $(p<0.05)$ between $0.5 \mathrm{~h}^{125} \mathrm{I}$ and $3 \mathrm{~h}^{125} \mathrm{I}$; ${ }^{\mathrm{e}}$ significant difference $(p<0.05)$ between $0.5 \mathrm{~h}{ }^{125} \mathrm{I}$ and $24 \mathrm{~h}^{125} \mathrm{I}^{\mathrm{f}}$ significant difference $(p<0.05)$ between $3 \mathrm{~h}^{125} \mathrm{I}$ and $24 \mathrm{~h}{ }^{125} \mathrm{I}$; $\mathrm{g}$ significant difference $(p<0.05)$ between $0.5 \mathrm{~h}^{111} \mathrm{In}$ and $3 \mathrm{~h}^{111} \mathrm{In}$; ${ }^{\mathrm{h}}$ significant difference $(p<0.05)$ between $0.5 \mathrm{~h}^{111} \mathrm{In}$ and $24 \mathrm{~h}^{111}$ In ${ }^{\mathrm{i}}{ }^{\mathrm{i}}$ significant difference $(p<0.05)$ between $3 \mathrm{~h}{ }^{111}$ In and $24 \mathrm{~h}^{111}$ In. 
3.5.2. Biodistribution of [ $\left.{ }^{125} \mathrm{I}\right] \mathrm{I}-\mathrm{Tyr}-\mathrm{PEG}_{2}-\mathrm{RM} 26$ in NMRI Mice by Co-Injection of Phosphoramidon $(\mathrm{PA})$ as an In Vivo Stabilizer

Influence of co-injection of the enzyme inhibitor phosphoramidon (PA) on in vivo stabilization of the radiopeptide $\left[{ }^{125} \mathrm{I}\right] \mathrm{I}-\mathrm{Tyr}-\mathrm{PEG}_{2}-\mathrm{RM} 26$ in non-tumour bearing mice was investigated. This strategy led to a remarkable enhanced uptake of the radiopeptides in tumour and receptor-expressing tissues, whereas uptake in most non-target organs and tissues was not affected. Results from the biodistribution study of $\left[{ }^{125} \mathrm{I}\right] \mathrm{I}-\mathrm{Ty}-\mathrm{PEG}_{2}-\mathrm{RM} 26$ are summarized in Figure 8 . No significant increase of uptake in GRPR-positive organs (pancreas, small intestines, and stomach) was observed at $0.5 \mathrm{~h}$ after co-injection of PA. Moreover, co-injection of PA did not show any significant influence on blood clearance rate or uptake in normal non-targeted organs and tissues.

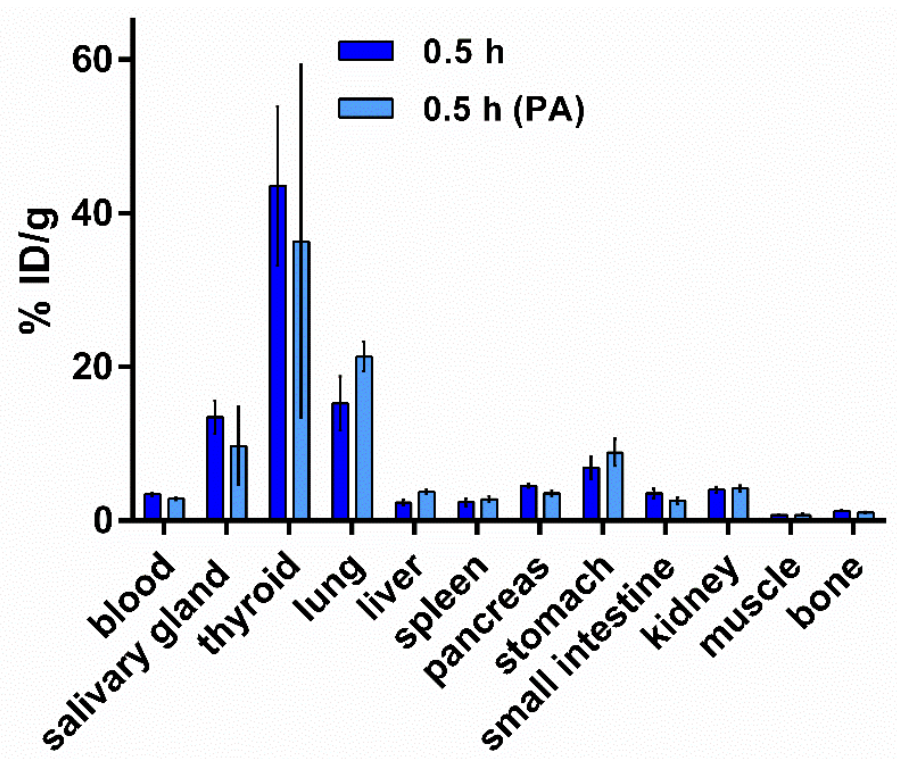

Figure 8. Effect of phosphoramidon (PA) on the biodistribution of [ $\left.{ }^{125} \mathrm{I}\right] \mathrm{I}-\mathrm{Ty}$ r-PEG $2-\mathrm{RM} 26$. Non-tumour bearing mice as the control group were intravenously injected with $40 \mathrm{pmol}$ of $\left[{ }^{125} \mathrm{I}\right] \mathrm{I}-\mathrm{Tyr}-\mathrm{PEG} 2-\mathrm{RM} 26$ $(30 \mathrm{kBq}, 100 \mu \mathrm{L}$ in PBS) into the tail vein. Another group of mice was injected with same activity with co-injection of PA (15 $\mu \mathrm{L}$ of $20 \mathrm{mg} / \mathrm{mL}$ of stock solution, $300 \mu \mathrm{g})$.

\section{Discussion}

The goal of this study was to test the hypothesis that use of non-residualizing radioiodine might offer advantages in radionuclide therapy when antagonistic, slowly internalizing bombesin analogues are used for targeting. For this purpose, bombesin analogue Tyr-PEG $2-\mathrm{RM} 26$ was synthesized, purified, and characterized (Figure 2). Tyr-PEG $2-\mathrm{RM} 26$ was successfully radiolabelled with ${ }^{125} \mathrm{I}$ with good radiochemical yield and about 95\% purity. The label was stable in PBS and under challenge with large molar excess of sodium iodide.

The lipophilicity test showed that $\left[{ }^{125} \mathrm{I}\right] \mathrm{I}-\mathrm{Tyr}-\mathrm{PEG}_{2}-\mathrm{RM} 26$ is appreciably more lipophilic than [111 In]In-DOTA-PEG $2-R M 26$. All further biological tests in vitro and in vivo aiming at the comparison of $\left.{ }^{[125} \mathrm{I}\right] \mathrm{I}-\mathrm{Tyr}-\mathrm{PEG}_{2}-\mathrm{RM} 26$ and [111 In]In-DOTA-PEG $2-\mathrm{RM} 26$ were performed with cells of the same passage and in a single batch of animals. Such design of the study eliminates uncertainties associated with possible changes of cell properties due to clonal selection during multiple passages and batch-to-batch variability of laboratory animals. [ $\left.{ }^{125} \mathrm{I}\right] \mathrm{I}-\mathrm{Ty}-\mathrm{PEG}_{2}-\mathrm{RM} 26$ maintained specific in vitro binding to GRPR-expressing cells, which was proportional to the expression level $\left(2.5 \times 10^{5}\right.$ and $1.2 \times 10^{4}$ receptors per cell for PC-3 and DU-145 [44], respectively (Figure 3). IC 50 -values for Tyr-PEG $-\mathrm{PM}_{26}$ and DOTA-PEG $2-R M 26$ were in the low nanomolar range (Figure 4). Binding of Tyr-PEG - RM26 to GRPR $\left(\mathrm{IC}_{50}=1.7 \pm 0.3 \mathrm{nM}\right)$ was somewhat stronger than binding of DOTA-PEG $-\mathrm{RM} 26\left(\mathrm{IC}_{50}=3.2 \pm 0.5 \mathrm{nM}\right)$. 
This is in agreement with previous data showing that a negative charge on $\mathrm{N}$-terminus is unfavourable for binding of bombesin analogues to GRPR [31,33].

The cellular processing of $\left.{ }^{[111} \mathrm{In}\right] \mathrm{In}-\mathrm{DOTA}-\mathrm{PEG}_{2}-\mathrm{RM} 26$ (Figure 5) was characteristic for radiometal-labelled antagonistic analogues of bombesin [32-37]. The internalization was slow reaching $14 \%$ of cell-associated radioactivity after $24 \mathrm{~h}$ incubation. Cell-associated activity of $\left[{ }^{125} \mathrm{I}\right] \mathrm{I}-\mathrm{Tyr}-\mathrm{PEG}_{2}-\mathrm{RM} 26$ showed rapid increase during the first hour followed by decrease over time. Such type of cellular processing resembles the behaviour of radioiodinated GRPR-binding agonists, when rapid internalization is followed by intracellular degradation and leakage of radiometabolites. However, the internalization and efflux rates of $\left[{ }^{125} \mathrm{I}\right] \mathrm{I}-\mathrm{Tyr}-\mathrm{PEG}_{2}-\mathrm{RM} 26$ were much slower than the rates for GRPR-binding agonists. Internalization of agonistic [ $\left.{ }^{125} \mathrm{I}\right] \mathrm{I}-\mathrm{GRP}$ and $\left[{ }^{125} \mathrm{I}\right] \mathrm{I}-\mathrm{Tyr}{ }^{4}-\mathrm{BBN}$ was $75-80 \%$ within 20-40 $\mathrm{min}[19,45]$. The decrease in cell-associated activity may be explained by lysosomal degradation of internalized radioiodinated conjugate followed by excretion of radiocatabolites and recycling of GRPR membrane surface [46,47]. These recycled GRPR can further bind and internalize [ $\left.{ }^{125} \mathrm{I}\right] \mathrm{I}-\mathrm{Tyr}-\mathrm{PEG}_{2}-\mathrm{RM} 26$ existing in media. Although retention of cell-associated activity for $\left[{ }^{125} \mathrm{I}\right] \mathrm{I}-\mathrm{Tyr}-\mathrm{PEG}_{2}-\mathrm{RM} 26$ was much worse than for the metal labelled RM26, it was better for this antagonistic agent than should be expected for agonistic ones. Efflux of $45-65 \%$ of cell associated activity was reported both for residualizing $\left({ }^{111} \mathrm{In}\right.$-DOTA and ${ }^{99 \mathrm{~m}} \mathrm{Tc}\left((\mathrm{CO})_{3}\right)$ and non-residualizing labels $\left({ }^{18} \mathrm{~F}\right.$-benzoate and $\left.{ }^{125} \mathrm{I}-\mathrm{Tyr}\right)$ attached to agonists $[19,48,49]$.

Previous studies have shown that use of lysosomotropic bases can reduce lysosomal degradation of radiohalogenated targeting agents and increase intercellular retention and uptake [50]. To check lysosomal degradation of [ $\left.{ }^{125} \mathrm{I}\right] \mathrm{I}-\mathrm{Tyr}-\mathrm{PEG}_{2}-\mathrm{RM} 26$, treatment with lysosomotropic bases was performed. The results of this test showed significantly $(p<0.05)$ increased cell-bound activity and retention of [ $\left.{ }^{125} \mathrm{I}\right] \mathrm{I}-\mathrm{Tyr}-\mathrm{PEG}_{2}-\mathrm{RM} 26$ in the presence of chloroquine or ammonium chloride (Figure 6). This confirms that internalization and lysosomal degradation play an essential role in the decrease of cell-associated activity of $\left[{ }^{125} \mathrm{I}\right] \mathrm{I}-\mathrm{Tyr}-\mathrm{PEG}_{2}-\mathrm{RM} 26$. Overall, the results of the in vitro evaluation show very unusual cellular processing pattern for an antagonist. It is possible that coupling of a quite lipophilic tyrosine at N-terminus triggers internalization of $\left[{ }^{125} \mathrm{I}\right] \mathrm{I}-\mathrm{Ty}-\mathrm{PEG}_{2}-\mathrm{RM} 26$. It has to be noted that previous studies have demonstrated that introduction of the chelator may affect the functional (agonism/antagonism) profile of targeting peptides. For example, the antagonistic somatostatin analogue (H-Cpa-DCys-Asn-Phe-Phe-DTrp-Lys-Thr-PheThr-Cys-2Nal-NH 2 , 406-040-15) linked to DOTA as the chelator switched its pharmacological function to an agonist [51]. In that study, authors concluded that prediction of the influence of a peptide modification on its functional profile by adding a chelator is not possible and properties has to be tested experimentally. This study demonstrates for the first time that the internalization pattern of bombesin analogues might be changed by modification of the $\mathrm{N}$-terminus. This may be an important information to consider in molecular design of radiolabelled peptides.

We have used a dual label approach for comparison of $\left[{ }^{125} \mathrm{I}\right] \mathrm{I}-\mathrm{Ty}-\mathrm{PEG}_{2}-\mathrm{RM} 26$ and [111 In]In-DOTA-PEG 2 -RM26, when two labelled conjugates are co-injected in the same mice, and the uptake of different labels in tissue is determined by gamma-spectroscopy. In this way, all factors related to an animal (e.g., hormonal status, heart rate, renal function) and to a tumour (e.g., vascularization, vascular permeability, and a target expression level) influence biodistribution of both compounds in the same way. This permits to reveal a significant diffidence in biodistribution with relatively low number of animals. The in vivo specificity study (Figure 7) showed that uptake of both [ $\left.{ }^{125} \mathrm{I}\right] \mathrm{I}-\mathrm{Tyr}-\mathrm{PEG}_{2}-\mathrm{RM} 26$ and [111 In]In-DOTA-PEG ${ }_{2}$-RM26 in tumours and GRPR-expressing tissues was specific. By co-injection with an excess of non-labelled peptide, tumour uptake was significantly $(p<0.05)$ reduced from $13 \pm 5 \% \mathrm{ID} / \mathrm{g}$ to $1 \pm 0 \% \mathrm{ID} / \mathrm{g}$ for [ $\left.{ }^{111} \mathrm{In}\right] \mathrm{In}-\mathrm{DOTA}-\mathrm{PEG}_{2}-\mathrm{RM} 26$ and from $7 \pm 1 \% \mathrm{ID} / \mathrm{g}$ to $5 \pm 1 \% \mathrm{ID} / \mathrm{g}$ for $\left[{ }^{125} \mathrm{I}\right] \mathrm{I}-\mathrm{Tyr}-\mathrm{PEG}_{2}-\mathrm{RM} 26$, indicating specific GRPR-mediated uptake. There was a significant $(p<0.05)$ reduction of the uptake of both tracers in GRPR-expressing pancreatic tissue.

The biodistribution of [ $\left.{ }^{125} \mathrm{I}\right] \mathrm{I}-\mathrm{Ty} r-\mathrm{PEG}_{2}-\mathrm{RM} 26$ and [ $\left.{ }^{111} \mathrm{In}\right] \mathrm{In}-\mathrm{DOTA}-\mathrm{PEG}_{2}-\mathrm{RM} 26$ in mice was quite different. Biodistribution of [ $\left.{ }^{111} \mathrm{In}\right] \mathrm{In}-\mathrm{DOTA}-\mathrm{PEG}_{2}-\mathrm{RM} 26$ was characterized by a rapid clearance 
of radioactivity from blood, GRPR-expressing organs, and other healthy organs and tissues, and the excretion of radioactivity was predominantly via kidney filtration. Clearance of activity from blood and other tissues after injection of [ $\left.{ }^{125} \mathrm{I}\right] \mathrm{I}-\mathrm{Ty}-\mathrm{PEG}_{2}-\mathrm{RM} 26$ was noticeably slower and there was an appreciable hepatic uptake. The high accumulation of activity in organs with expression of $\mathrm{Na} / \mathrm{I}-$ symporters (thyroid, salivary glands and stomach) was observed for [ $\left.{ }^{125} \mathrm{I}\right] \mathrm{I}-\mathrm{Ty}-\mathrm{PEG} 2-\mathrm{RM} 26$, which indicates a re-distribution of radiometabolites. Tumor uptake for [ $\left.{ }^{111} \mathrm{In}\right] \mathrm{In}-\mathrm{DOTA}-\mathrm{PEG} 2-\mathrm{RM} 26$ $(13 \pm 5 \% \mathrm{ID} / \mathrm{g})$ was significantly $(p<0.05)$ higher than for $\left[{ }^{125} \mathrm{I}\right] \mathrm{I}-\mathrm{Ty} r-\mathrm{PEG}_{2}-\mathrm{RM} 26(7 \pm 1 \% \mathrm{ID} / \mathrm{g})$ at $0.5 \mathrm{~h}$ after injection.

Tumor uptake of [ $\left.{ }^{125} \mathrm{I}\right] \mathrm{I}-\mathrm{Ty}$ r-PEG $2-\mathrm{RM} 26$ decreased more than 3-fold at $3 \mathrm{~h}$ compared to $0.5 \mathrm{~h}$ after injection, while decrease of tumour uptake was not so dramatic for [ $\left.{ }^{111} \mathrm{In}\right] \mathrm{In}-\mathrm{DOTA}-\mathrm{PEG}{ }_{2}-\mathrm{RM}_{2} 6$. The clearance of [ $\left.{ }^{111} \mathrm{In}\right] \mathrm{In}-\mathrm{DOTA}-\mathrm{PEG}_{2}-\mathrm{RM} 26$ from non-targeted organs was very fast, which resulted in a significant $(p<0.05)$ higher tumour-to-organ ratio at $3 \mathrm{~h}$ after injection.

Due to the relatively small size of the peptides, modification of their structure can influence their affinity and selectivity for the targeted receptors. Previous studies of X-PEG ${ }_{2}-R M 26(X=N O T A$, NODAGA, DOTA, and DOTAGA) containing different chelators labelled with ${ }^{111}$ In and ${ }^{68}$ Ga showed that changing the radiometal and chelator can substantially influence the affinity and biodistribution profile [31,41]. All analogues showed antagonistic properties confirmed by the slow internalization rate after binding to the GRPR.

Degradation of radiopeptides, including bombesin-like peptides, by proteolytic enzymes present in blood, vasculature walls, liver, lungs, kidney, and gastrointestinal tract limits their successful application as theranostic probes $[52,53]$. These enzymes can potentially hamper radiopeptide-based imaging and therapy by cleaving radiopeptides into inactive radiometabolites. Previous studies have shown that co-injection of the enzyme inhibitor phosphoramidon (PA), can stabilize radiopeptides in vivo, resulting in a remarkable increase of tumour uptake, whereas uptake in non-target healthy organs and tissues is not affected [54]. The results of biodistribution of [ $\left.{ }^{125} \mathrm{I}\right] \mathrm{I}-\mathrm{Ty}$-PEG2-RM26 in non-tumourbearing mice demonstrated that co-injection of PA could not improve blood clearance rate or uptake in healthy organs and tissues. Thereby, degradation of radiolabelled conjugate cannot be the main reason for the high uptake in non-targeted organs and slow blood clearance rate.

Taken together, in vitro and in vivo data suggest that conjugation of tyrosine at N-terminus of $\mathrm{PEG}_{2}-\mathrm{RM} 26$ results in an appreciably more rapid internalization compared to the internalization of $\mathrm{PEG}_{2}-\mathrm{RM} 26$ with DOTA conjugated at N-terminus. The use of a non-residualizing radiohalogen label causes a poor retention of activity by malignant cells both in vitro and in vivo. Furthermore, blood clearance of [ $\left.{ }^{125} \mathrm{I}\right] \mathrm{I}-\mathrm{Ty}$ r-PEG $2-\mathrm{RM} 26$ is slower comparing to [ $\left.{ }^{111} \mathrm{In}\right] \mathrm{In}-\mathrm{DOTA}-\mathrm{PEG}_{2}-\mathrm{RM} 26$. Studies with other peptides $[55,56]$ suggest that slow clearance might be due to binding of blood proteins caused by an elevated lipophilicity. Overall, such features are undesirable for radionuclide therapy.

The undesirable features of $\left[{ }^{125} \mathrm{I}\right] \mathrm{I}-\mathrm{Tyr}-\mathrm{PEG}_{2}-\mathrm{RM} 26$ are highly likely associated with the presence of lipophilic side-chain of tyrosine at N-terminus. At the same time, the presence of phenolic moiety is critical for radioiodination and endowing of non-residualizing property of the label. Obviously, the improved molecular design of a GRPR antagonist with non-residualizing label should keep the presence of a tyrosine at N-terminus but foresee a compensation of its lipophilicity. Earlier studies have shown that increase of overall and local hydrophilicity of targeted polypeptides by incorporation of amino acids with polar or charged side-chain in a proximity to a label facilitates their blood clearance $[57,58]$ and reduces hepatic uptake [57-60]. An incorporation of a glutamate had the strongest benign affect in these studies. However, both this and previous studies $[33,34]$ show that a placement of negatively charged moiety decreases affinity of RM26 binding to GRPR. Therefore, we consider the use of amino acids with neutral polar or positively charged side-chains, i.e., glutamine and lysine. For preliminary assessment of hydrophilicity of the combination of these amino acids with tyrosine, logP of the oligopeptides was calculated using ChemDraw Ultra assuming amidated C-tremini (CambfidgeSoft, Cambridge, MA, USA) and compared with $\log \mathrm{P}$ of tyrosine (Figure 9). 
<smiles>CNC(Cc1ccc(O)cc1)C(N)=O</smiles>

$\log \mathrm{P}=-0.26$ (b)<smiles>CNC(=O)C(CCC(N)=O)NC(=O)C(Cc1ccc(O)cc1)NC</smiles>

$\log \mathrm{P}=-3.07$<smiles>CNC(=O)C(CCCCN)NC(=O)C(N)Cc1ccc(O)cc1</smiles>

$\log \mathrm{P}=-1.87$<smiles>NC(=O)CCC(NC(=O)C(CCC(N)=O)NC(=O)C(N)Cc1ccc(O)cc1)C(N)=O</smiles>

$\log \mathrm{P}=-5.11$<smiles>NC(=O)CCC(NC(=O)C(CCCC[NH3+])NC(=O)[C@H](N)Cc1ccc(O)cc1)C(N)=O</smiles>

$\log \mathrm{P}=-3.94$

Figure 9. Structures of N-termini containing (a) Tyr; (b) Tyr-Gln; (c) Tyr-Lys; (d) Tyr-Gln-Gln; (e) Tyr-Gln-Lys and their $\log \mathrm{P}$ calculated using ChemDraw Ultra.

Apparently, addition of glutamine and lysine to tyrosine would enhance hydrophilicity of the $\mathrm{N}$-terminus of tyrosine-containing RM26 analogue. Particularly a Tyr-Gln-Gln-combination looks promising. The obvious next step should be preparation of a small library of RM26 analogues containing both tyrosine and glutamine and their comparative evaluation.

\section{Conclusions}

The results showed that use of [ $\left.{ }^{125} \mathrm{I}\right] \mathrm{I}-\mathrm{Tyr}-\mathrm{PEG}_{2}-\mathrm{RM} 26$ was not advantageously for radionuclide targeting of PC compared with [ ${ }^{111} \mathrm{In}$ ]In-DOTA-PEG $2-\mathrm{RM} 26$ as hypothesized. An introduction of a hydrophobic tyrosine group at N-terminus of RM26 changed cellular processing and biodistribution patterns of antagonistic bombesin analogue making them unfavourable for radionuclide therapy. Incorporation of amino acids with hydrophilic side-chains in the proximity to tyrosine might improve the biodistribution pattern of a radioiodinated tyrosine-containing RM26 analogue.

Author Contributions: Conceptualization, M.O., V.T. and U.R.; Data curation, V.T.; Formal analysis, M.O., A.A., F.L., B.M., A.O., V.T., and U.R.; Funding acquisition, A.O. and V.T.; Investigation, M.O., A.A., F.L., B.M., A.O., V.T., and U.R.; Project administration, U.R.; Supervision, A.O., V.T. and U.R.; Writing-original draft, M.O.; Writing-review \& editing, M.O., A.A., F.L., B.M., A.O., V.T., and U.R.

Funding: This study was supported by the Swedish Cancer Society (grants CAN 2017/425 (A.O.), CAN 2018/436 (V.T.)), the Swedish Research Council (grants 2015-02509 (A.O.), 2015-02353 (V.T.)).

Acknowledgments: This research was financially supported by grants from the Swedish Cancer Society (Cancerfonden) and the Swedish Research Council (Vetenskapsrådet).

Conflicts of Interest: The authors declare no conflict of interest.

\section{References}

1. Siegel, R.L.; Miller, K.D.; Jemal, A. Cancer statistics, 2018. CA Cancer J. Clin. 2018, 68, 7-30. [CrossRef] [PubMed] 
2. Aragon-Ching, J.B. The evolution of prostate cancer therapy: Targeting the androgen receptor. Front. Oncol. 2014, 4, 295. [CrossRef] [PubMed]

3. Yuan, X.; Cai, C.; Chen, S.; Yu, Z.; Balk, S.P. Androgen receptor functions in castration-resistant prostate cancer and mechanisms of resistance to new agents targeting the androgen axis. Oncogene 2014, 33, 2815-2825. [CrossRef] [PubMed]

4. $\quad$ Emmett, L.; Willowson, K.; Violet, J.; Shin, J.; Blanksby, A.; Lee, J. Lutetium 177 PSMA radionuclide therapy for men with prostate cancer: A review of the current literature and discussion of practical aspects of therapy. J. Med. Radiat. Sci. 2017, 64, 52-60. [CrossRef] [PubMed]

5. Kratochwil, C.; Bruchertseifer, F.; Rathke, H.; Hohenfellner, M.; Giesel, F.L.; Haberkorn, U.; Morgenstern, A. Targeted $\alpha$-Therapy of Metastatic Castration-Resistant Prostate Cancer with 225Ac-PSMA-617: Dosimetry Estimate and Empiric Dose Finding. J. Nucl. Med. 2017, 58, 1624-1631. [CrossRef] [PubMed]

6. Silver, D.A.; Pellicer, I.; Fair, W.R.; Heston, W.D.; Cordon-Cardo, C. Prostate-specific membrane antigen expression in normal and malignant human tissues. Clin. Cancer Res. 1997, 3, 81-85. [PubMed]

7. Spatz, S.; Tolkach, Y.; Jung, K.; Stephan, C.; Busch, J.; Ralla, B.; Rabien, A.; Feldmann, G.; Brossart, P.; Bundschuh, R.A.; et al. Comprehensive evaluation of prostate-specific membrane antigen expression in the vasculature of renal tumors: implications for imaging studies and prognostic role. J. Urol. 2018, 199, 370-377.

8. Sheikhbahaei, S.; Afshar-Oromieh, A.; Eiber, M.; Solnes, L.B.; Javadi, M.S.; Ross, A.E.; Pienta, K.J.; Allaf, M.E.; Haberkorn, U.; Pomper, M.G.; et al. Pearls and pitfalls in clinical interpretation of prostate-specific membrane antigen (PSMA)-targeted PET imaging. Eur. J. Nucl. Med. Mol. Imaging 2017, 44, 2117-2136. [CrossRef] [PubMed]

9. Ananias, H.J.; van den Heuvel, M.C.; Helfrich, W.; de Jong, I.J. Expression of the gastrin-releasing peptide receptor, the prostate stem cell antigen and the prostate-specific membrane antigen in lymph node and bone metastases of prostate cancer. Prostate 2009, 69, 1101-1108. [CrossRef]

10. Reubi, J.C. Peptide receptors as molecular targets for cancer diagnosis and therapy. Endocr. Rev. 2003, 2, 389-427. [CrossRef]

11. Van de Wiele, C.; Dumont, F.; Vanden Broecke, R.; Oosterlinck, W.; Cocquyt, V.; Serreyn, R.; Peers, S.; Thornback, J.; Slegers, G.; Dierckx, R.A. Technetium-99m RP527, a GRP analogue for visualisation of GRP receptor-expressing malignancies: A feasibility study. Eur. J. Nucl. Med. 2000, 27, 1694-1699. [CrossRef]

12. Jensen, R.T.; Battey, J.F.; Spindel, E.R.; Benya, R.V. International Union of Pharmacology. LXVIII. Mammalian bombesin receptors: Nomenclature, distribution, pharmacology, signaling, and functions in normal and disease states. Pharmacol. Rev. 2008, 60,1-42. [CrossRef] [PubMed]

13. Nock, B.A.; Nikolopoulou, A.; Galanis, A.; Cordopatis, P.; Waser, B.; Reubi, J.C.; Maina, T. Potent bombesin-like peptides for GRP-receptor targeting of tumors with ${ }^{99 \mathrm{~m}} \mathrm{Tc}$ : A preclinical study. J. Med. Chem. 2005, 48, 100-110. [CrossRef] [PubMed]

14. Zhang, X.; Cai, W.; Cao, F.; Schreibmann, E.; Wu, Y.; Wu, J.C.; Xing, L.; Chen, X. 18F-labeled bombesin analogs for targeting GRP receptor-expressing prostate cancer. J. Nucl. Med. 2006, 47, 492-501. [PubMed]

15. Dimitrakopoulou-Strauss, A.; Hohenberger, P.; Haberkorn, U.; Macke, H.R.; Eisenhut, M.; Strauss, L.G. ${ }^{68} \mathrm{Ga}$-labeled bombesin studies in patients with gastrointestinal stromal tumors: Comparison with 18F-FDG. J. Nucl. Med. 2007, 48, 1245-1250. [CrossRef] [PubMed]

16. Däpp, S.; Müller, C.; Garayoa, E.G.; Bläuenstein, P.; Maes, V.; Brans, L.; Tourwé, D.A.; Schibli, R. PEGylation, increasing specific activity and multiple dosing as strategies to improve the risk-benefit profile of targeted radionuclide therapy with ${ }^{177}$ Lu-DOTA-bombesin analogues. EJNMMI Res. 2012, 2, 24-36. [CrossRef] [PubMed]

17. Wild, D.; Frischknecht, M.; Zhang, H.; Morgenstern, A.; Bruchertseifer, F.; Boisclair, J.; Provencher-Bolliger, A.; Reubi, J.C.; Maecke, H.R. Alpha- versus beta-particle radiopeptide therapy in a human prostate cancer model ( ${ }^{213}$ Bi-DOTA-PESIN and ${ }^{213}$ Bi-AMBA versus ${ }^{177}$ Lu-DOTA-PESIN). Cancer Res. 2011, 71, 1009-1018. [CrossRef]

18. Smith, C.J.; Sieckman, G.L.; Owen, N.K.; Hayes, D.L.; Mazuru, D.G.; Volkert, W.A.; Hoffman, T.J. Radiochemical investigations of $\left[188 \mathrm{Re}\left(\mathrm{H}_{2} \mathrm{O}\right)(\mathrm{CO})_{3}\right.$-diaminopropionic acid-SSS-bombesin $\left.(7-14) \mathrm{NH}_{2}\right]$ : Syntheses, radiolabeling and in vitro/in vivo GRP receptor targeting studies. Anticancer Res. 2003, 23, 63-70. 
19. Lantry, L.E.; Cappelletti, E.; Maddalena, M.E.; Fox, J.S.; Feng, W.; Chen, J.; Thomas, R.; Eaton, S.M.; Bogdan, N.J.; Arunachalam, T.; et al. ${ }^{177} \mathrm{Lu}-\mathrm{AMBA}$ : Synthesis and characterization of a selective ${ }^{177} \mathrm{Lu}$-labeled GRP-R agonist for systemic radiotherapy of prostate cancer. J. Nucl. Med. 2006, 47, 1144-1152.

20. Koumarianou, E.; Mikołajczak, R.; Pawlak, D.; Zikos, X.; Bouziotis, P.; Garnuszek, P.; Karczmarczyk, U.; Maurin, M.; Archimandritis, S.C. Comparative study on DOTA-derivatized bombesin analog labeled with ${ }^{90} \mathrm{Y}$ and ${ }^{177} \mathrm{Lu}$ : In vitro and in vivo evaluation. Nucl. Med. Biol. 2009, 36, 591-603. [CrossRef]

21. Nock, B.; Nikolopoulou, A.; Chiotellis, E.; Loudos, G.; Maintas, D.; Reubi, J.C.; Maina, T. [99m Tc]Demobesin 1, a novel potent bombesin analogue for GRP receptor-targeted tumour imaging. Eur. J. Nucl. Med. 2003, 30, 247-258. [CrossRef]

22. Abiraj, K.; Mansi, R.; Tamma, M.L.; Fani, M.; Forrer, F.; Nicolas, G.; Cescato, R.; Reubi, J.C.; Maecke, H.R. Bombesin antagonist-based radioligands for translational nuclear imaging of gastrin-releasing peptide receptor-positive tumors. J. Nucl. Med. 2011, 52, 1970-1978. [CrossRef] [PubMed]

23. Cescato, R.; Maina, T.; Nock, B.; Nikolopoulou, A.; Charalambidis, D.; Piccand, V.; Reubi, J.C. Bombesin Receptor Antagonists May Be Preferable to Agonists for Tumor Targeting. J. Nucl. Med. 2008, 49, 318-326. [CrossRef] [PubMed]

24. Mansi, R.; Wang, X.; Forrer, F.; Kneifel, S.; Tamma, M.L.; Waser, B.; Cescato, R.; Reubi, J.C.; Maecke, H.R. Evaluation of a 1,4,7,10-tetraazacyclododecane-1,4,7,10-tetraacetic acid-conjugated bombesin-based radioantagonist for the labeling with single-photon emission computed tomography, positron emission tomography, and therapeutic radionuclides. Clin. Cancer Res. 2009, 15, 5240-5249. [CrossRef] [PubMed]

25. Dumont, R.A.; Tamma, M.; Braun, F.; Borkowski, S.; Reubi, J.C.; Maecke, H.; Weber, W.A.; Mansi, R. Targeted radiotherapy of prostate cancer with a gastrin-releasing peptide receptor antagonist is effective as monotherapy and in combination with rapamycin. J. Nucl. Med. 2013, 54, 762-769. [CrossRef] [PubMed]

26. Chatalic, K.L.; Konijnenberg, M.; Nonnekens, J.; de Blois, E.; Hoeben, S.; de Ridder, C.; Brunel, L.; Fehrentz, J.A.; Martinez, J.; van Gent, D.C.; et al. In Vivo Stabilization of a Gastrin-Releasing Peptide Receptor Antagonist Enhances PET Imaging and Radionuclide Therapy of Prostate Cancer in Preclinical Studies. Theranostics 2016, 6, 104-117. [CrossRef] [PubMed]

27. Nock, B.A.; Kaloudi, A.; Lymperis, E.; Giarika, A.; Kulkarni, H.R.; Klette, I.; Singh, A.; Krenning, E.P.; de Jong, M.; Maina, T.; et al. Theranostic Perspectives in Prostate Cancer with the Gastrin-Releasing Peptide Receptor Antagonist NeoBOMB1: Preclinical and First Clinical Results. J. Nucl. Med. 2017, 58, 75-80. [CrossRef] [PubMed]

28. Tolmachev, V.; Mume, E.; Sjöberg, S.; Frejd, F.Y.; Orlova, A. Influence of valency and labelling chemistry on in vivo targeting using radioiodinated $\mathrm{HER}_{2}$-binding Affibody molecules. Eur. J. Nucl. Med. Mol. Imaging 2009, 36, 692-701. [CrossRef]

29. Lindbo, S.; Garousi, J.; Mitran, B.; Altai, M.; Buijs, J.; Orlova, A.; Hober, S.; Tolmachev, V. Radionuclide Tumor Targeting Using ADAPT Scaffold Proteins: Aspects of Label Positioning and Residualizing Properties of the Label. J. Nucl. Med. 2018, 59, 93-99. [CrossRef]

30. Wilbur, S. Radiohalogenation of proteins: An overview of radionuclides, labeling methods and reagents for conjugate labeling. Bioconjug. Chem. 1992, 3, 433-470. [CrossRef]

31. Llinares, M.; Devin, C.; Chaloin, O.; Azay, J.; Noel-Artis, A.M.; Bernad, N.; Fehrentz, J.A.; Martinez, J. Syntheses and biological activities of potent bombesin receptor antagonists. J. Pept. Res. 1999, 53, $275-283$. [CrossRef]

32. Varasteh, Z.; Velikyan, I.; Lindeberg, G.; Sörensen, J.; Larhed, M.; Sandström, M.; Selvaraju, R.K.; Malmberg, J.; Tolmachev, V.; Orlova, A. Synthesis and characterization of a high-affinity NOTA-conjugated bombesin antagonist for GRPR-targeted tumour imaging. Bioconjug. Chem. 2013, 24, 1144-1153. [CrossRef] [PubMed]

33. Varasteh, Z.; Rosenström, U.; Velikyan, I.; Mitran, B.; Altai, M.; Honarvar, H.; Rosestedt, M.; Lindeberg, G.; Sörensen, J.; Larhed, M.; et al. The effect of mini-PEG-based spacer length on binding and pharmacokinetic properties of a ${ }^{68} \mathrm{Ga}$-labeled NOTA-conjugated antagonistic analog of bombesin. Molecules 2014, 19, 10455-10472. [CrossRef] [PubMed]

34. Varasteh, Z.; Mitran, B.; Rosenström, U.; Velikyan, I.; Rosestedt, M.; Lindeberg, G.; Sörensen, J.; Larhed, M.; Tolmachev, V.; Orlova, A. The effect of macrocyclic chelators on the targeting properties of the ${ }^{68}$ Ga-labeled gastrin releasing peptide receptor antagonist PEG2-RM26. Nucl. Med. Biol. 2015, 42, 446-454. [CrossRef] [PubMed] 
35. Varasteh, Z.; Aberg, O.; Velikyan, I.; Lindeberg, G.; Sörensen, J.; Larhed, M.; Antoni, G.; Sandström, M.; Tolmachev, V.; Orlova, A. In vitro and in vivo evaluation of a (18)F-labeled high affinity NOTA conjugated bombesin antagonist as a PET ligand for GRPR-targeted tumor imaging. PLoS ONE 2013, 8, e81932. [CrossRef] [PubMed]

36. Mitran, B.; Thisgaard, H.; Rosenström, U.; Dam, J.H.; Larhed, M.; Tolmachev, V.; Orlova, A. High Contrast PET Imaging of GRPR Expression in Prostate Cancer Using Cobalt-Labeled Bombesin Antagonist RM26. Contrast Media Mol. Imaging 2017, 2017, 6873684. [CrossRef] [PubMed]

37. Mitran, B.; Rinne, S.S.; Konijnenberg, M.W.; Maina, T.; Nock, B.A.; Altai, M.; Vorobyeva, A.; Larhed, M.; Tolmachev, V.; de Jong, M.; et al. Trastuzumab co-treatment improves survival of mice with PC-3 prostate cancer xenografts treated with the GRPR antagonist ${ }^{177}$ Lu-DOTAGA-PEG $2-R M 26$. Int. J. Cancer. 2019. [CrossRef] [PubMed]

38. Moody, T.W.; Crawley, J.N.; Jensen, R.T. Pharmacology and neurochemistry of bombesin like peptides. Peptides 1982, 3, 559-563. [CrossRef]

39. Biddlecombe, G.B.; Rogers, B.E.; de Visser, M.; Parry, J.J.; de Jong, M.; Erion, J.L.; Lewis, J.S. Molecular imaging of gastrin-releasing peptide receptor-positive tumors in mice using ${ }^{64} \mathrm{Cu}-$ and ${ }^{86}$ Y-DOTA-(Pro ${ }^{1}$, Tyr $^{4}$ )-bombesin(1-14). Bioconjug. Chem. 2007, 18, 724-730. [CrossRef]

40. Hoffman, T.J.; Gali, H.; Smith, C.J.; Sieckman, G.L.; Hayes, D.L.; Owen, N.K.; Volkert, W.A. Novel series of ${ }^{111}$ In-labeled bombesin analogs as potential radiopharmaceuticals for specific targeting of gastrin-releasing peptide receptors expressed on human prostate cancer cells. J. Nucl. Med. 2003, 44, 823-831.

41. Mitran, B.; Varasteh, Z.; Selvaraju, R.K.; Lindeberg, G.; Sörensen, J.; Larhed, M.; Tolmachev, V.; Rosenström, U.; Orlova, A. Selection of optimal chelator improves the contrast of GRPR imaging using bombesin analogue RM26. Int. J. Oncol. 2016, 48, 2124-2134. [CrossRef]

42. Láznícek, M.; Kvĕtina, J.; Mazák, J.; Krch, V. Plasma protein binding—lipophilicity relationships: Interspecies comparison of some organic acids. J. Pharm. Pharmacol. 1987, 39, 79-83. [CrossRef]

43. Wållberg, H.; Orlova, A. Slow intenalisation of anti-HER 2 synthetic affibody monomer

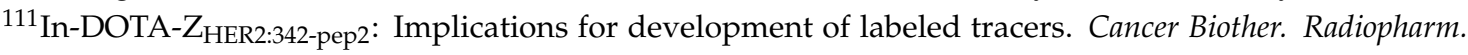
2008, 23, 435-442. [CrossRef]

44. Maddalena, M.E.; Fox, J.; Chen, J.; Feng, W.; Cagnolini, A.; Linder, K.E.; Tweedle, M.F.; Nunn, A.D.; Lantry, L.E. ${ }^{177} \mathrm{Lu}-\mathrm{AMBA}$ biodistribution, radiotherapeutic efficacy, imaging, and autoradiography in prostate cancer models with low GRP-R expression. J. Nucl. Med. 2009, 50, 2017-2024. [CrossRef]

45. Grady, E.F.; Slice, L.W.; Brant, W.O.; Walsh, J.H.; Payan, D.G.; Bunnett, N.W. Direct observation of endocytosis of gastrin releasing peptide and its receptor. J. Biol. Chem. 1995, 270, 4603-4611. [CrossRef]

46. La Bella, R.; Garcia-Garayoa, E.; Bahler, M.; Bläuenstein, P.; Schibli, R.; Conrath, P.; Tourwé, D.; Schubiger, P.A. A ${ }^{99} \mathrm{~m} \mathrm{Tc}(\mathrm{I})$-postlabeled high affinity bombesin analogue as a potential tumor imaging agent. Bioconjug. Chem. 2002, 13, 599-604. [CrossRef]

47. García Garayoa, E.; Schweinsberg, C.; Maes, V.; Rüegg, D.; Blanc, A.; Bläuenstein, P.; Tourwé, D.A.; Beck-Sickinger, A.G.; Schubiger, P.A. New $\left[{ }^{99 \mathrm{~m}} \mathrm{Tc}\right]$ bombesin analogues with improved biodistribution for targeting gastrin releasing-peptide receptor-positive tumors. J. Nucl. Med. Mol. Imaging 2007, 51, 42-50.

48. Zhang, H.; Chen, J.; Waldherr, C.; Hinni, K.; Waser, B.; Reubi, J.C.; Maecke, H.R. Synthesis and evaluation of bombesin derivatives on the basis of pan-bombesin peptides labeled with indium-111, lutetium-177, and yttrium-90 for targeting bombesin receptor-expressing tumors. Cancer Res. 2004, 64, 6707-6715. [CrossRef]

49. García Garayoa, E.; Schweinsberg, C.; Maes, V.; Brans, L.; Bläuenstein, P.; Tourwe, D.A.; Schibli, R.; Schubiger, P.A. Influence of the molecular charge on the biodistribution of bombesin analogues labeled with the $\left[{ }^{99 \mathrm{~m}} \mathrm{Tc}(\mathrm{CO})_{3}\right]$-core. Bioconjug. Chem. 2008, 19, 2409-2416. [CrossRef]

50. Sundberg, A.L.; Steffen, A. C Enhancing the effect of radionuclide tumor targeting, using lysosomotropic weak bases. Int. J. Radiat. Oncol. Biol. Phys. 2007, 67, 279-287. [CrossRef]

51. Reubi, J.C.; Erchegyi, J.; Cescato, R.; Waser, B.; Rivier, J.E. Switch from antagonist to agonist after addition of a DOTA chelator to a somatostatin analog. Eur. J. Nucl. Med. Mol. Imaging 2010, 37, 1551-1558. [CrossRef]

52. Shipp, M.A.; Tarr, G.E.; Chen, C.Y.; Switzer, S.N.; Hersh, L.B.; Stein, H.; Sunday, M.E.; Reinherz, E.L. CD10/neutral endopeptidase 24.11 hydrolyzes bombesin-like peptides and regulates the growth of small cell carcinomas of the lung. Proc. Natl. Acad. Sci. USA 1991, 88, 10662-10666. [CrossRef]

53. Roques, B.P.; Noble, F.; Dauge, V.; Fournié-Zaluski, M.C.; Beaumont, A. Neutral endopeptidase 24.11: Structure, inhibition, and experimental and clinical pharmacology. Pharmacol. Rev. 1993, 45, 87-146. 
54. Nock, B.A.; Maina, T.; Krenning, E.P.; de Jong, M. “To serve and protect”: Enzyme inhibitors as radiopeptide escorts promote tumor targeting. J. Nucl. Med. 2014, 55, 121-127. [CrossRef]

55. Wittendorf, R.W.; Swagzdis, J.E.; Gifford, R.; Mico, B.A. Protein binding of glycopeptide antibiotics with diverse physical-chemical properties in mouse, rat, and human serum. J. Pharmacokinet. Biopharm. 1987, 15, 5-13. [CrossRef]

56. Decristoforo, C.; Mather, S.J. 99m-Technetium-labelled peptide-HYNIC conjugates: Effects of lipophilicity and stability on biodistribution. Nucl. Med. Biol. 1999, 26, 389-396. [CrossRef]

57. Engfeldt, T.; Tran, T.; Orlova, A.; Widström, C.; Feldwisch, J.; Abrahmsen, L.; Wennborg, A.; Karlström, A.E.; Tolmachev, V. ${ }^{99 \mathrm{~m}} \mathrm{Tc}$-chelator engineering to improve tumour targeting properties of a HER 2 -specific Affibody molecule. Eur. J. Nucl. Med. Mol. Imaging 2007, 34, 1843-1853. [CrossRef]

58. Tran, T.; Engfeldt, T.; Orlova, A.; Sandström, M.; Feldwisch, J.; Abrahmsén, L.; Wennborg, A.; Tolmachev, V.; Karlström, A.E. ${ }^{99 \mathrm{~m}}$ Tc-maEEE-Z $\mathrm{HER}_{\mathrm{H}: 342}$, an Affibody molecule-based tracer for the detection of $\mathrm{HER}_{2}$ expression in malignant tumors. Bioconjug. Chem. 2007, 18, 1956-1964. [CrossRef]

59. Rusckowski, M.; Qu, T.; Gupta, S.; Ley, A.; Hnatowich, D.J. A comparison in monkeys of ${ }^{99 \mathrm{~m}}$ Tc labeled to a peptide by 4 methods. J. Nucl. Med. 2001, 42, 1870-1877.

60. Rosik, D.; Thibblin, A.; Antoni, G.; Honarvar, H.; Strand, J.; Selvaraju, R.K.; Altai, M.; Orlova, A.; Eriksson Karlström, A.; Tolmachev, V. Incorporation of a triglutamyl spacer improves the biodistribution of synthetic affibody molecules radiofluorinated at the N-terminus via oxime formation with (18)F-4-fluorobenzaldehyde. Bioconjug. Chem. 2014, 25, 82-92. [CrossRef]

(C) 2019 by the authors. Licensee MDPI, Basel, Switzerland. This article is an open access article distributed under the terms and conditions of the Creative Commons Attribution (CC BY) license (http://creativecommons.org/licenses/by/4.0/). 